Toxic Substances Hydrology Program

Fisheries: Aquatic and Endangered Resources Program

Contaminant Biology Program

Prepared in cooperation with the

U.S. Environmental Protection Agency and the

Massachusetts Division of Fisheries and Wildlife

\title{
Prevalence of Tumors in Brown Bullhead from Three Lakes in Southeastern Massachusetts, 2002
}
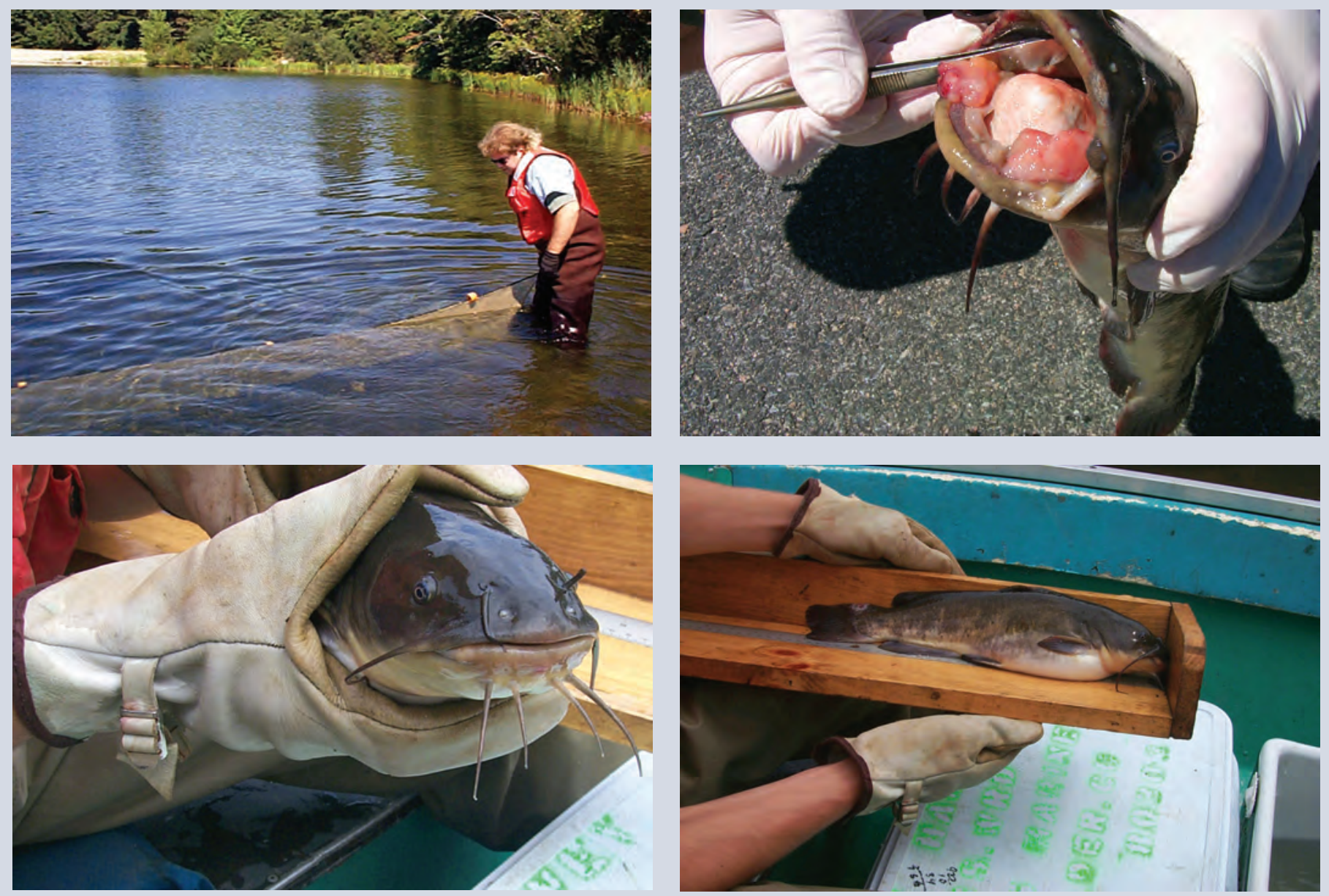

Scientific Investigations Report 2008-5198

U.S. Department of the Interior

U.S. Geological Survey 
Cover. Photographs (clockwise from top left) showing $(A)$ deployment of a fyke net in Ashumet Pond, $(B)$ oral lesions in brown bullhead, (C) side view of brown bullhead as its length is being measured, and (D) front view of brown bullhead. 


\section{Prevalence of Tumors in Brown Bullhead from Three Lakes in Southeastern Massachusetts, 2002}

By Paul C. Baumann'1, Denis R. LeBlanc'', Vicki S. Blazer', John R. Meier', Stephen T. Hurley², and Yasu Kiryu'

${ }^{1}$ U.S. Geological Survey

${ }^{2}$ Massachusetts Division of Fisheries and Wildlife, Buzzards Bay, Massachusetts

${ }^{3}$ U.S. Environmental Protection Agency, Cincinnati, Ohio

Toxic Substances Hydrology Program

Fisheries: Aquatic and Endangered Resources Program

Contaminant Biology Program

Prepared in cooperation with the U.S. Environmental Protection Agency and the Massachusetts Division of Fisheries and Wildlife

Scientific Investigations Report 2008-5198 


\title{
U.S. Department of the Interior DIRK KEMPTHORNE, Secretary
}

\author{
U.S. Geological Survey \\ Mark D. Myers, Director
}

U.S. Geological Survey, Reston, Virginia: 2008

For more information on the USGS — the Federal source for science about the Earth, its natural and living resources, natural hazards, and the environment:

World Wide Web: http://www.usgs.gov

Telephone: 1-888-ASK-USGS

Any use of trade, product, or firm names is for descriptive purposes only and does not imply endorsement by the U.S. Government.

Although this report is in the public domain, permission must be secured from the individual copyright owners to reproduce any copyrighted materials contained within this report.

Suggested citation:

Baumann, P.C., LeBlanc, D.R., Blazer, V.S., Meier, J.R., Hurley, S.T., and Kiryu, Yasu, 2008, Prevalence of tumors in brown bullhead from three lakes in southeastern Massachusetts, 2002: U.S. Geological Survey Scientific Investigations Report 2008-5198, 43 p., available online at http://pubs.usgs.gov/sir/2008/5198. 


\section{Contents}

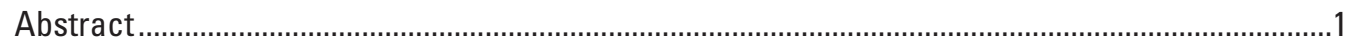

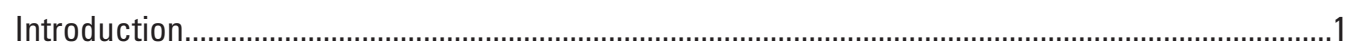

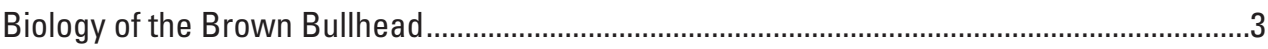

Geographic and Hydrologic Setting .................................................................................... 4

Previous Studies of Tumor Prevalence .....................................................................................

Lake Selection and Field and Laboratory Methods ......................................................................4

Lake Selection and Characteristics....................................................................................... 5

Field Collection Methods .....................................................................................................

External Examination, Blood Sampling, and Necropsy ......................................................10

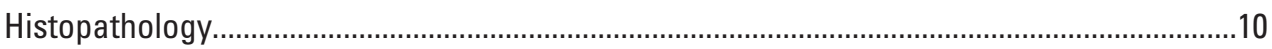

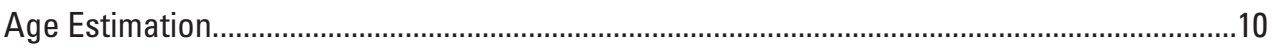

Blood Analysis by Comet Assays ..................................................................................... 12

Statistical Methods................................................................................................................... 12

Prevalence of Tumors in Brown Bullhead ..................................................................................... 13

Size and Age Distributions ........................................................................................................ 13

Prevalence of External Raised Lesions.....................................................................................13

Prevalence of Barbel Deformities............................................................................................ 14

Histopathology of External Lesions ....................................................................................... 14

Histopathology of the Liver, Spleen, and Kidney ..................................................................16

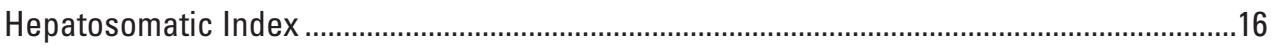

DNA Damage in Red Blood Cells .................................................................................... 16

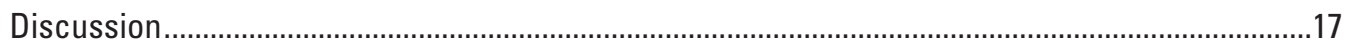

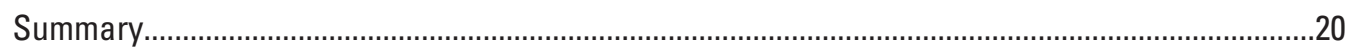

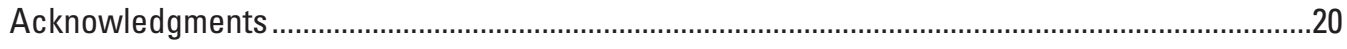

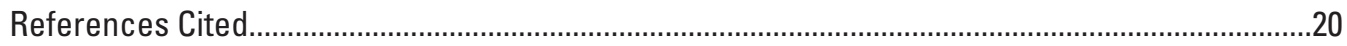

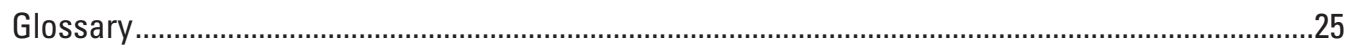

Appendix 1. Selected Characteristics of Brown Bullhead (Ameiurus nebulosus) Collected from Ashumet, Santuit, and Great Herring Ponds, Southeastern Massachusetts, and Examined Externally in the Field, May-July 2002

Appendix 2. Selected Characteristics of Brown Bullhead (Ameiurus nebulosus) Collected from Ashumet, Santuit, and Great Herring Ponds, Southeastern Massachusetts, and Necropsied for Internal Examination and Tissue Sampling, May-June 2002.

\section{Figures}

1. Map showing locations of Ashumet, Johns, Santuit, and Great Herring Ponds, the Massachusetts Military Reservation (MMR), and the plumes of ground-water contamination from the MMR in 2007, southeastern Massachusetts.

2. Photograph showing brown bullhead (Ameiurus nebulosus) from Ashumet Pond, Cape Cod, Massachusetts, with normal barbels and no apparent external lesions, May 2002 
3-5. Maps showing-

3. Topographic setting, water-table contours, plumes of ground-water contamination in 2007, and paths of drainage swales from the Massachusetts Military Reservation near Ashumet Pond, Falmouth and Mashpee, Cape Cod, Massachusetts.

4. Topographic setting, water-table contours, and plumes of ground-water contamination from the Massachusetts Military Reservation in 2007 near Santuit Pond, Barnstable, Cape Cod, Massachusetts.

5. Topographic setting, water-table contours, and the sea-level Cape Cod Canal near Great Herring Pond, Plymouth, southeastern Massachusetts

6. Photographs showing two examples of brown bullhead (Ameiurus nebulosus) from Ashumet Pond, Cape Cod, Massachusetts, with body-surface and oral lesions and shortened barbels, May 2002.

7. Images of Comet assays showing $(A)$ assay of blood sample from a Cape Cod, Massachusetts, brown bullhead (Ameiurus nebulosus) and (B) interpretation of a typical assay.

8-9. Graphs showing-

8. Prevalences of large (greater than 6 millimeters) raised oral and body-surface lesions in brown bullhead (Ameiurus nebulosus) from Great Herring, Santuit, and Ashumet Ponds, Cape Cod, Massachusetts, May-July 2002.

9. Prevalences of multiple external lesions and melanistic patches in brown bullhead (Ameiurus nebulosus) from Great Herring, Santuit, and Ashumet Ponds, Cape Cod, Massachusetts, May-July 2002

10. Images showing selected microscopic findings in tissues of brown bullhead (Ameiurus nebulosus) from Ashumet Pond, Cape Cod, Massachusetts, May 2002

11. Graph showing prevalence of raised external lesions in brown bullhead (Ameiurus nebulosus) from tributaries of the Great Lakes, rivers in the eastern United States and Canada, and Ashumet, Santuit, and Great Herring Ponds on Cape Cod, Massachusetts

\section{Tables}

1. Chi-square statistical comparison of combined raised-lesion prevalence in brown bullhead (Ameiurus nebulosus) in the 1990s from Ashumet and Johns Ponds to the combined prevalence in three reference lakes, Cape Cod, Massachusetts

2. Hydrologic characteristics of Ashumet, Santuit, and Great Herring Ponds, southeastern Massachusetts

3. Numbers of brown bullhead (Ameiurus nebulosus) sampled by location and date from Ashumet, Santuit, and Great Herring Ponds, southeastern Massachusetts, May-July 2002.

4. Percentage by location of brown bullhead (Ameiurus nebulosus) having external raised lesions, Ashumet, Santuit, and Great Herring Ponds, southeastern Massachusetts, May-July 2002

5. Percentage by location of brown bullhead (Ameiurus nebulosus) having barbel abnormalities, including missing, shortened, and knobbed barbels, Ashumet, Santuit, and Great Herring Ponds, southeastern Massachusetts, May-July 2002 
6. Percentage of necropsied brown bullhead (Ameiurus nebulosus) having selected microscopic lesions observed in liver tissue, Ashumet, Santuit, and Great Herring

Ponds, southeastern Massachusetts, May-July 2002.

7. Hepatosomatic index (liver weight divided by body weight) of brown bullhead (Ameiurus nebulosus) from Ashumet, Santuit, and Great Herring Ponds, southeastern Massachusetts, May-July 2002

8. Red blood cell nucleic DNA damage as determined by the Comet assay for brown bullhead (Ameiurus nebulosus) from Ashumet and Great Herring Ponds, southeastern Massachusetts, May-July 2002

\section{Conversion Factors, Datum, and Abbreviations}

\begin{tabular}{|c|c|c|}
\hline Multiply & By & To obtain \\
\hline \multicolumn{3}{|c|}{ Length } \\
\hline inch (in.) & 2.54 & centimeter $(\mathrm{cm})$ \\
\hline inch (in.) & 25.4 & millimeter $(\mathrm{mm})$ \\
\hline inch (in.) & 25,400 & micrometer $(\mu \mathrm{m})$ \\
\hline foot (ft) & 0.3048 & meter $(\mathrm{m})$ \\
\hline mile (mi) & 1.609 & kilometer (km) \\
\hline \multicolumn{3}{|c|}{ Area } \\
\hline acre & 0.4047 & hectare (ha) \\
\hline \multicolumn{3}{|c|}{ Volume } \\
\hline ounce, fluid (fl. oz) & 29.57 & milliliter (mL) \\
\hline ounce, fluid (fl. oz) & 29,570 & microliter $(\mu \mathrm{L})$ \\
\hline gallon (gal) & 3.785 & liter (L) \\
\hline \multicolumn{3}{|c|}{ Mass } \\
\hline ounce, avoirdupois (oz) & 28.35 & gram $(\mathrm{g})$ \\
\hline ounce, avoirdupois (oz) & 28,350 & milligram (mg) \\
\hline pound, avoirdupois (lb) & 0.4536 & kilogram $(\mathrm{kg})$ \\
\hline
\end{tabular}

Temperature in degrees Celsius $\left({ }^{\circ} \mathrm{C}\right)$ may be converted to degrees Fahrenheit $\left({ }^{\circ} \mathrm{F}\right)$ as follows: ${ }^{\circ} \mathrm{F}=\left(1.8 \times^{\circ} \mathrm{C}\right)+32$

Vertical coordinate information is referenced to the National Geodetic Vertical Datum of 1929 (NGVD 29).

Altitude, as used in this report, refers to distance above the vertical datum.

Chemical concentration in water is given in units of milligrams per liter $(\mathrm{mg} / \mathrm{L})$ or micrograms per liter $(\mu \mathrm{g} / \mathrm{L})$. Chemical concentration in sediment is given in units of micrograms per kilogram $(\mu \mathrm{g} / \mathrm{kg})$. Sediment concentrations are sometimes expressed in parts per billion (ppb), which is equivalent to $\mu \mathrm{g} / \mathrm{kg}$. 


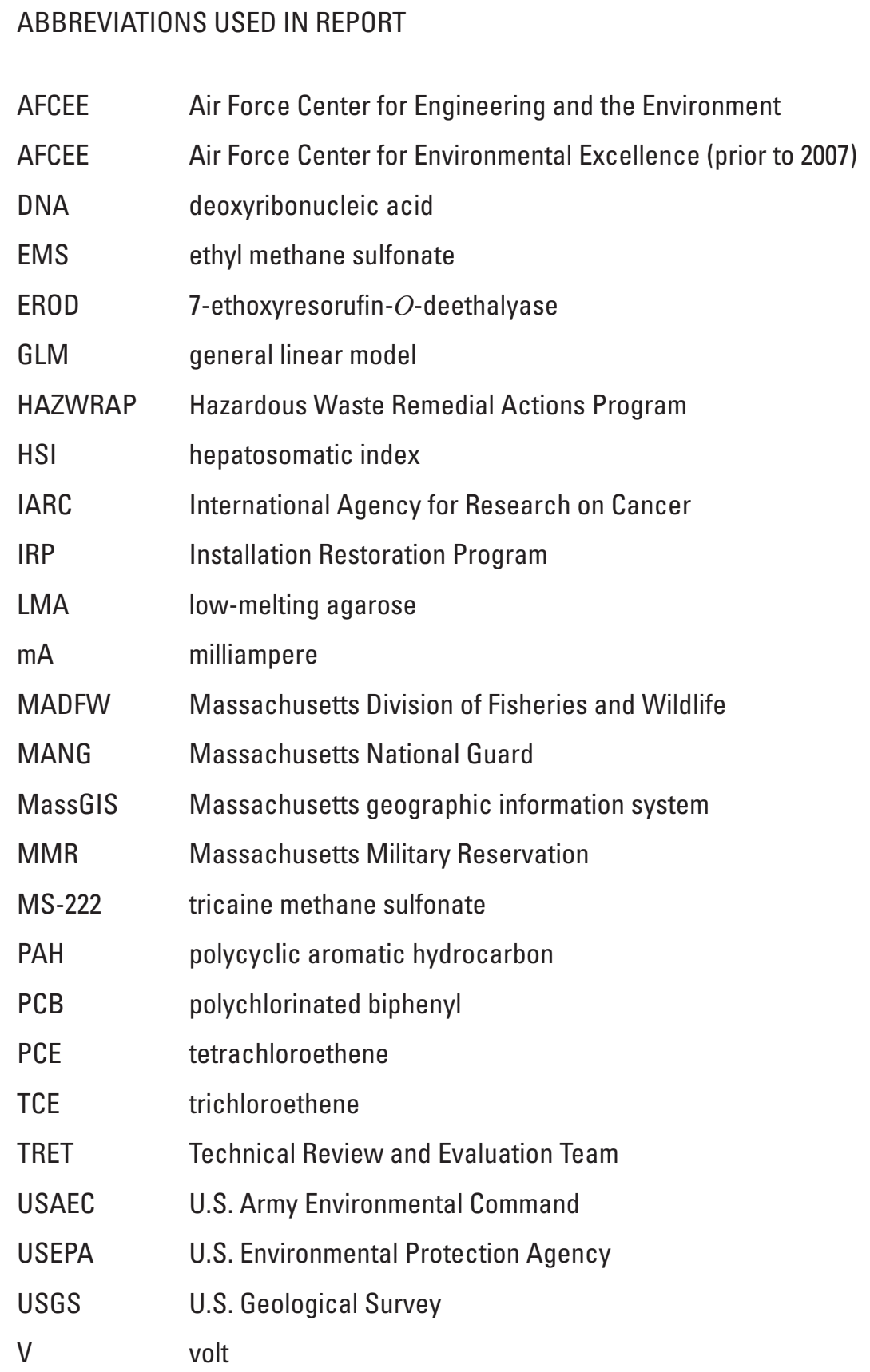




\title{
Prevalence of Tumors in Brown Bullhead from Three Lakes in Southeastern Massachusetts, 2002
}

\author{
By Paul C. Baumann, Denis R. LeBlanc, Vicki S. Blazer, John R. Meier, Stephen T. Hurley, and Yasu Kiryu
}

\section{Abstract}

The Massachusetts Military Reservation (MMR) has been a military base on western Cape Cod since the early 1900s. Contaminated surface water and ground water from the MMR have discharged into several kettle lakes on or near the base. To discover whether the prevalences of tumors and other lesions in brown bullhead (Ameiurus nebulosus) in these lakes, particularly Ashumet Pond, were elevated above normal, the U.S. Geological Survey (USGS), assisted by the U.S. Environmental Protection Agency (USEPA) and the Massachusetts Division of Fisheries and Wildlife (MADFW), conducted a study in 2002 of brown bullhead in Ashumet Pond and in two reference lakes, Santuit Pond (on Cape Cod) and Great Herring Pond (on the mainland of Massachusetts). Brown bullhead from Great Herring Pond had few external raised lesions (2.8 percent), a low prevalence of liver neoplasms (5 percent), and little genetic damage to their red blood cell nuclei. Brown bullhead from Ashumet Pond had a high prevalence of raised lesions (62.1 percent), which included histopathologically verified papillomas and squamous carcinoma; an elevated incidence of liver neoplasms (16.7 percent); and an elevated level of genetic damage to their red blood cell nuclei. Because red blood cells in fish have a lifespan of about 100 days, these results indicate an ongoing exposure to genotoxins in Ashumet Pond. Brown bullhead from Santuit Pond also had elevated prevalences of raised lesions (48.3 percent) and liver neoplasms (15 percent), although the prevalences of large and multiple lesions were significantly lower than those in fish from Ashumet Pond. These differences may indicate differing causes of pathology in the two lakes. The high prevalence of melanistic lesions on brown bullhead from Ashumet Pond, combined with the tumor pathology and genetic damage, implicates chemical carcinogens as one of the causal factors in that lake.

\section{Introduction}

Many kettle lakes in the glacial sand and gravel deposits of southeastern Massachusetts support populations of brown bullhead (Ameiurus nebulosus). These fish, a species of catfish also known locally as hornpout, feed on the organisms in the bottom sediments of the lakes. Bullhead use barbels, which are whisker-like sensory organs in contact with the sediments, to find their food (Scott and Crossman, 1973). Because bullhead spend much of their time in contact with the bottom sediments, the development of liver tumors ${ }^{1}$, including hepatic (liver cell) and biliary (bile duct cell) tumors, in these fish has been linked to contaminants, particularly polycyclic aromatic hydrocarbons (PAHs), in the sediments (Baumann and others, 1996; Baumann and Okihiro, 2000). Although skin tumors, including papillomas and squamous carcinoma, have been initiated in brown bullhead in the laboratory by using PAHs extracted from sediment (Black, 1983), there are probably multiple causal factors for such external tumors (Baumann and others, 1996). These tumors have been (and continue to be) used as an indicator of environmental health (Baumann, 1992).

The Massachusetts Military Reservation (MMR), which has been a multiuse military facility on western Cape Cod (fig. 1) since the early 1900s (Rolbein, 1995; Massachusetts National Guard (MANG), 2008), is adjacent to several large kettle lakes. Plumes of contaminated ground water from the MMR (fig. 1) discharge to several of these lakes (Savoie and others, 2000; McCobb and others, 2003; Air Force Center for Environmental Excellence (AFCEE), 2005, 2007), and in the past, storm drainage from the runways was directed to adjacent lakes (Hazardous Waste Remedial Actions Program (HAZWRAP), 1986).

Several studies by the Installation Restoration Program (IRP) at the MMR in the 1990s reported that the prevalence (measured as percentage) of tumors on brown bullhead in two lakes (Ashumet and Johns Ponds, fig. 1) near the MMR was elevated relative to the prevalence in several reference lakes. There were concerns that these tumors were related to sources of contamination at the MMR, although cause and effect could not be established (AFCEE, 1997). In a review of these earlier studies, the Technical Review and Evaluation Team (TRET), a technical advisory group to the IRP, agreed with the finding of an elevated prevalence but noted that the numbers of fish sampled in the studies were small (AFCEE, 2008a). The TRET recommended that any future examination

${ }^{1}$ Terms listed in the glossary at the back of this report are in bold type where first used in the text. 


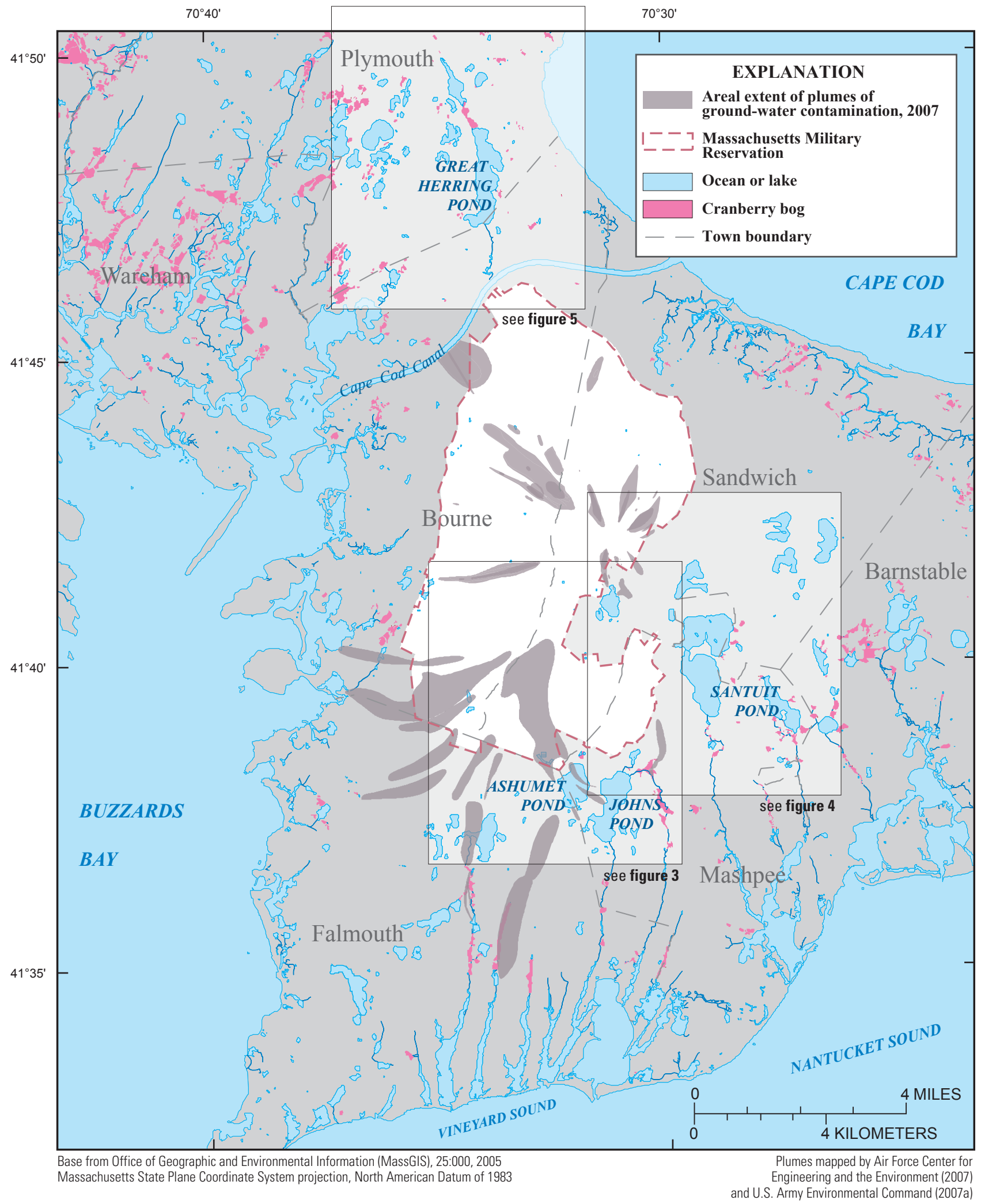

Figure 1. Locations of Ashumet, Johns, Santuit, and Great Herring Ponds, the Massachusetts Military Reservation (MMR), and the plumes of ground-water contamination from the MMR in 2007, southeastern Massachusetts. 
of the problem include a statistically based prevalence study that sampled more fish from the lakes of concern and similar reference lakes.

As a result of the TRET's recommendations, the U.S. Geological Survey (USGS) conducted a study in 2002 of the prevalence of tumors in brown bullhead in Ashumet Pond and two reference lakes, Santuit and Great Herring Ponds (fig. 1). The study was done in cooperation with the U.S. Environmental Protection Agency (USEPA) and the Massachusetts Division of Fisheries and Wildlife (MADFW). The objective of the study was to collect a sufficient number of brown bullhead from each lake to allow a test of the statistical significance of differences in tumor prevalence among the lakes. This study was not designed to address the causes of any elevated tumor frequency (see Discussion section).

This report describes the sampling effort, presents the data on the prevalence and characteristics of the tumors, and discusses the statistical significance of differences in tumor prevalence between Ashumet Pond and the two reference lakes. The report also presents results on the pathology of the tumors, as well as evidence from blood analysis of genetic damage in the brown bullhead. Finally, the results are compared with findings from the earlier studies at the MMR and from investigations of brown bullhead tumors in other lakes and rivers in North America.

\section{Biology of the Brown Bullhead}

The brown bullhead (fig. 2) is the most widely distributed of the native bullhead catfish, found from the Atlantic Ocean to the Gulf Coast watersheds and from eastern Canada to Alabama (Scott and Crossman, 1973). It is also native to the Great Lakes system, Hudson Bay, and the Mississippi River watershed. The specific epithet "nebulosus" means "clouded," referring to the fish's mottled sides. Brown bullhead can be distinguished from other bullhead by the whitish color at the base of the barbels and the square-tipped or only slightly rounded caudal fin. This species is common to lakes and slowmoving areas of rivers and is tolerant of warm water temperatures, low oxygen levels, and contamination. Like other catfish, brown bullhead are active primarily at night, when their sensory barbels help them locate food in the darkness. They are omnivorous bottom feeders that eat a wide variety of plant and animal material, including aquatic insects and other benthic invertebrates, small fish, and even algae. This feeding regime can result in a high exposure to contaminants in sediment, bottom waters, or invertebrates living in the sediment.

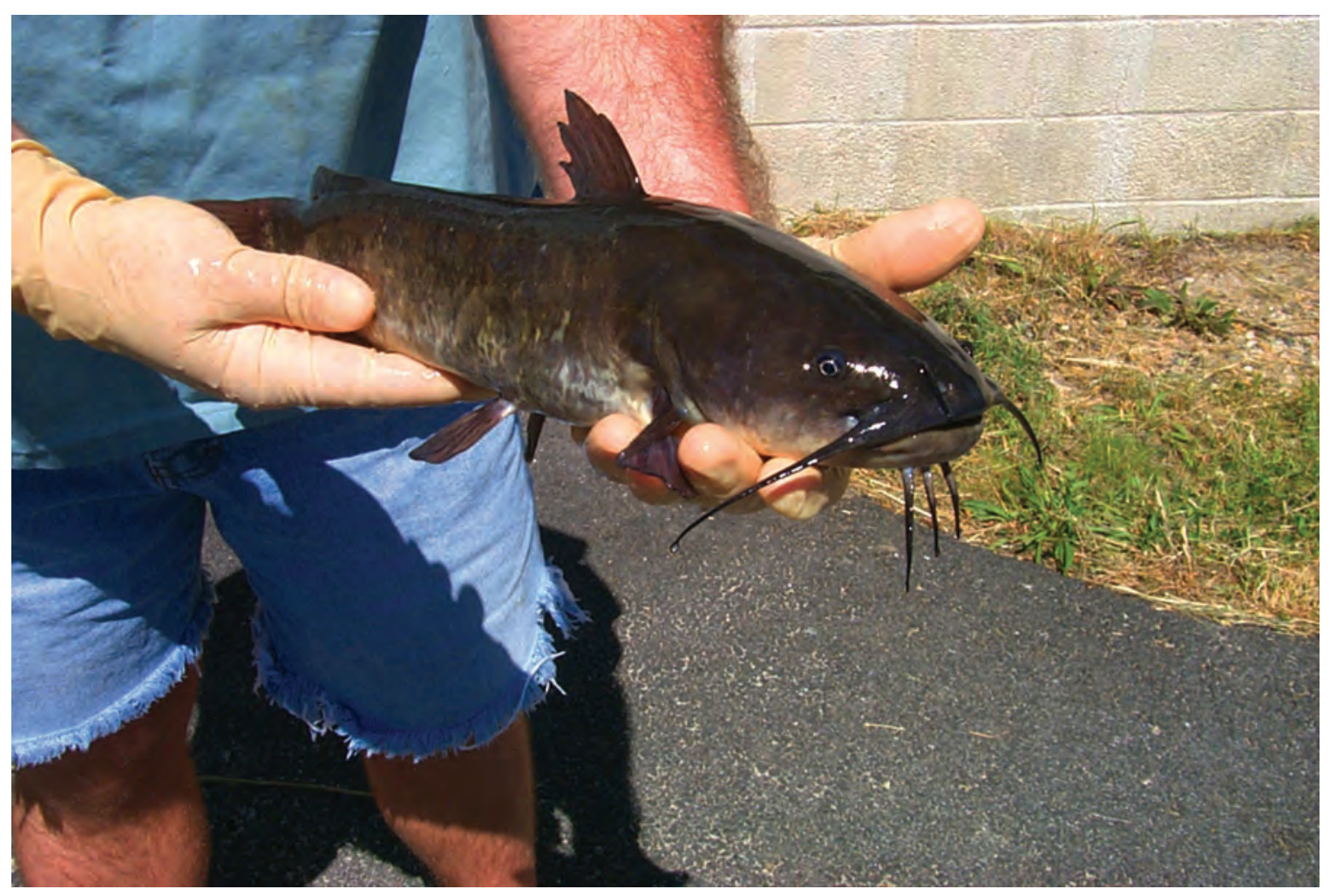

Figure 2. Brown bullhead (Ameiurus nebulosus) from Ashumet Pond, Cape Cod, Massachusetts, with normal barbels and no apparent external lesions, May 2002. 


\section{Geographic and Hydrologic Setting}

The study area in southeastern Massachusetts is characterized by extensive sand and gravel deposits from the last ice age (LeBlanc and others, 1986; Oldale and Barlow, 1986; Masterson and others, 1997). These glacial deposits are pitted with kettle lakes. Direct surface runoff to the lakes is limited because the soils are sandy and precipitation infiltrates the ground rapidly. The lakes are in direct hydraulic contact with the surrounding aquifer, and typically their water budgets are dominated by ground-water inflow and outflow seepage rather than by surface-water inflow and outflow (Masterson and others, 1998; Walter and others, 2002; Walter and Whealan, 2005).

Ashumet and Santuit Ponds are on Cape Cod and are separated hydraulically from the mainland by the sea-level Cape Cod Canal (fig. 1). Great Herring Pond is on the mainland in the Plymouth-Carver aquifer (Hansen and Lapham, 1990). The ground-water watersheds of the three lakes have similar land use and vegetation, except that the area north of Ashumet Pond includes the MMR (fig. 1).

Past military activities since the early 1900s at the MMR resulted in contamination of the Cape Cod aquifer (AFCEE, 2007; U.S. Army Environmental Command (USAEC), 2007a). More than a dozen plumes of contaminated ground water emanate from the MMR and extend toward the coast (fig. 1). The plumes contain industrial solvents, fuels and fuel additives, landfill leachate, treated-wastewater effluent, and, in the northern part of the base, explosives and propellants from military ordnance. These plumes are being remediated by the U.S. Department of Defense (AFCEE, 2007; USAEC, 2007b). Several plumes discharge to lakes and streams adjacent to the reservation (Savoie and others, 2000; AFCEE, 2005, 2007), although there is no information about these discharges prior 1986, the year when the IRP's plume investigations began.

\section{Previous Studies of Tumor Prevalence}

The earliest known observations of external lesions on brown bullhead on western Cape Cod were made by MADFW field crews in Johns Pond and its outflow, the Quashnet River, in October 1991 and May 1992 (Stephen T. Hurley, MADFW, Southeast Region, unpublished files, December 2007). Concerns that fish populations in Ashumet and Johns Ponds may have been exposed to contaminants from the MMR prompted a series of studies in the early 1990s. The first of these projects, conducted in 1992, noted a high prevalence of external tumors in brown bullhead from both Ashumet Pond (42 percent) and Johns Pond (67 percent) (HAZWRAP, 1995). In 1993, fish were collected again from Ashumet and Johns Ponds, as well as from Long, Coonamessett, and Grews Ponds in Falmouth (Stegeman, 1997). Finally, brown bullhead were examined from Ashumet and Johns Ponds, as well as from Long Pond in Brewster and Harwich, in spring 1994 and from these three lakes plus Upper Mill Pond in Brewster in fall
1994 (HAZWRAP, 1996). The numbers of fish collected for each site and time were relatively small, ranging from 2 to 30 , but were sufficient to indicate a potential problem.

Studies in the early 1990s (Stegeman, 1997) reported moderately but significantly elevated 7-ethoxyresorufin$O$-deethylase (EROD) and P4501A activity in brown bullhead collected from Ashumet and Johns Ponds compared to brown bullhead collected from Long and Coonamessett Ponds. The EROD and P450 assays are designed to measure the activity of these liver enzymes, which metabolize a variety of organic contaminants. Subsequent examination by other investigators of these enzymes in Cape Cod fish was inconclusive, however, because the measured enzyme activity varied significantly within and among the lakes sampled (AFCEE, 1997).

Prior to the initiation of the study described in this report, the tumor-prevalence data from the earlier studies near the MMR were combined from all sampling times for each location in order to do statistical testing (AFCEE, 2008b, c). Numbers of fish with and without external raised lesions from each location were entered in a contingency table (table 1), and tumor prevalence was examined for independence with a chisquare test. When all the sites were compared separately with each other, tumor prevalence was found to be significantly different among sites $(p<0.001)$. When the data from Ashumet and Johns Ponds were combined, and data from all of the other lakes were similarly combined as a reference prevalence, Ashumet and Johns Ponds were found to have a significantly higher incidence of external tumors $(p<0.001)$ (table 1). In combining the data to obtain sufficient sample numbers, seasonal and yearly fluctuations in tumor frequency were not considered. Also, data on fish age were not available. Despite these limitations, the large difference in tumor prevalence (37 percent for Ashumet and Johns Ponds compared to 7 percent for the reference lakes), along with the strong statistical significance, indicated that tumor prevalence in brown bullhead from Ashumet and Johns Ponds was higher than that in the reference lakes. This study was designed to provide data to determine tumor prevalence based on a larger sample size.

\section{Lake Selection and Field and Laboratory Methods}

The study included collection and examination of brown bullhead from three lakes to determine the prevalences of tumors and other lesions; histopathology of selected tissue samples to diagnose lesion types, which can provide evidence of lesion causation; and analysis of red blood cell nucleic damage, which can provide evidence of ongoing exposure to genotoxins. A detailed description of these methods is beyond the scope of this report. The reader is referred to Blazer and others (2007), Rafferty and Grazio (2006), and the other references at the end of the report for additional information. 
Table 1. Chi-square statistical comparison of combined raised-lesion prevalence in brown bullhead (Ameiurus nebulosus) in the 1990s from Ashumet and Johns Ponds to the combined prevalence in three reference lakes, Cape Cod, Massachusetts.

[Expected counts are included below observed counts. Source: Air Force Center for Engineering and the Environment (AFCEE) (2008b)]

\begin{tabular}{|c|c|c|c|c|}
\hline \multirow[b]{2}{*}{ Characteristic } & \multirow[b]{2}{*}{ Category } & \multicolumn{2}{|c|}{ Number of bullhead } & \multirow[b]{2}{*}{$\begin{array}{l}\text { Total number of } \\
\text { observed bullhead }\end{array}$} \\
\hline & & $\begin{array}{l}\text { Ashumet and } \\
\text { Johns Ponds }\end{array}$ & Reference lakes & \\
\hline \multirow[t]{2}{*}{ With external lesions } & Observed & 40 & 8 & 48 \\
\hline & Expected & 23.35 & 24.65 & \\
\hline \multirow[t]{2}{*}{ Without external lesions } & Observed & 67 & 105 & 172 \\
\hline & Expected & 83.65 & 88.35 & \\
\hline $\begin{array}{l}\text { Total number of observed } \\
\text { bullhead at all locations }\end{array}$ & & 107 & 113 & 220 \\
\hline
\end{tabular}

Chi-square statistic $=11.881+11.250+3.316+3.140=29.587$

Degrees of freedom $=1, p<0.001$

\section{Lake Selection and Characteristics}

Three lakes were included in this study-Ashumet Pond adjacent to the MMR and two reference lakes, Santuit and Great Herring Ponds (fig. 1). Selected characteristics of the three lakes are given in table 2 and described in MADFW (2008) and AFCEE (1997). Although it was included in the original design of the study, Johns Pond (fig. 1) was dropped because too few brown bullhead were collected from this lake.

The reference lakes were selected because they are similar to Ashumet and Johns Ponds in several ways. The groundwater contributing areas to the lakes are comparable in size (Masterson and Walter, 2000; John P. Masterson, U.S. Geological Survey, written commun., January 2008), and all the lakes receive substantial inflow from ground-water seepage, which generally is focused near the lake shore. The land use near the lakes, with the exception of the unique land use on the MMR near Ashumet and Johns Ponds, is similar among the lakes and includes residential areas with onsite septic systems, small cranberry bogs, and undeveloped, forested land. All the lakes are used for recreational motorized boating and fishing, particularly during the summer months. Finally, both Santuit and Great Herring Ponds were known to have large enough populations of brown bullhead to provide an adequate sample size in 2-3 days of collecting, and these lakes were within $10 \mathrm{mi}$ of the MMR to facilitate the field effort.

Ashumet Pond (fig. 3) is a classic ground-water flowthrough kettle lake (McCobb and others, 2003). The lake has no surface outlet and only a minor surface inlet from an abandoned cranberry bog at its northern end. Two drainage swales from the MMR airfield reach the lake (fig. 3). The swales channeled surface runoff to the cranberry bog and lake during particularly intense storms until 2002, when infiltration basins were installed on the MMR to capture the runoff (Robert Burt, 102nd Fighter Wing, Otis Air National Guard Base, written commun., December 2007). The runoff during the early 1950 s to the late 1960 s reportedly included dissolved and fluid-phase hydrocarbons (HAZWRAP, 1986; K-V Associates, Inc., and IEP, Inc., 1991; Stephen T. Hurley, MADFW, Southeast Region, unpublished files, December 2007); in the late 1960s, the Air Force began efforts, such as the installation of oil-water separators and berms, to limit hydrocarbon-contaminated runoff from reaching the lake.

PAHs, including known carcinogens, were found in sediment collected from Ashumet Pond (AFCEE, 1997). The results of sediment chemical analyses (Jon Davis, AFCEE, data retrieved from the IRP database on November 15, 2006) indicated that levels of PAHs from one sample location were somewhat elevated $(850 \mu \mathrm{g} / \mathrm{kg}$ for phenanthrene, fluoranthene, and pyrene combined) above values for these same compounds at five Great Lakes reference sites (304-527 $\mu \mathrm{g} / \mathrm{kg})$.

Table 2. Hydrologic characteristics of Ashumet, Santuit, and Great Herring Ponds, southeastern Massachusetts.

[Source: Massachusetts Division of Fisheries and Wildlife, 2008]

\begin{tabular}{lccc}
\hline \multicolumn{1}{c}{ Characteristic } & $\begin{array}{c}\text { Ashumet } \\
\text { Pond }\end{array}$ & $\begin{array}{c}\text { Santuit } \\
\text { Pond }\end{array}$ & $\begin{array}{c}\text { Great Herring } \\
\text { Pond }\end{array}$ \\
\hline Area in acres & 202 & 172 & 376 \\
Average depth in feet & 23 & 5 & 20 \\
Maximum depth in feet & 65 & 9 & 42 \\
\hline
\end{tabular}




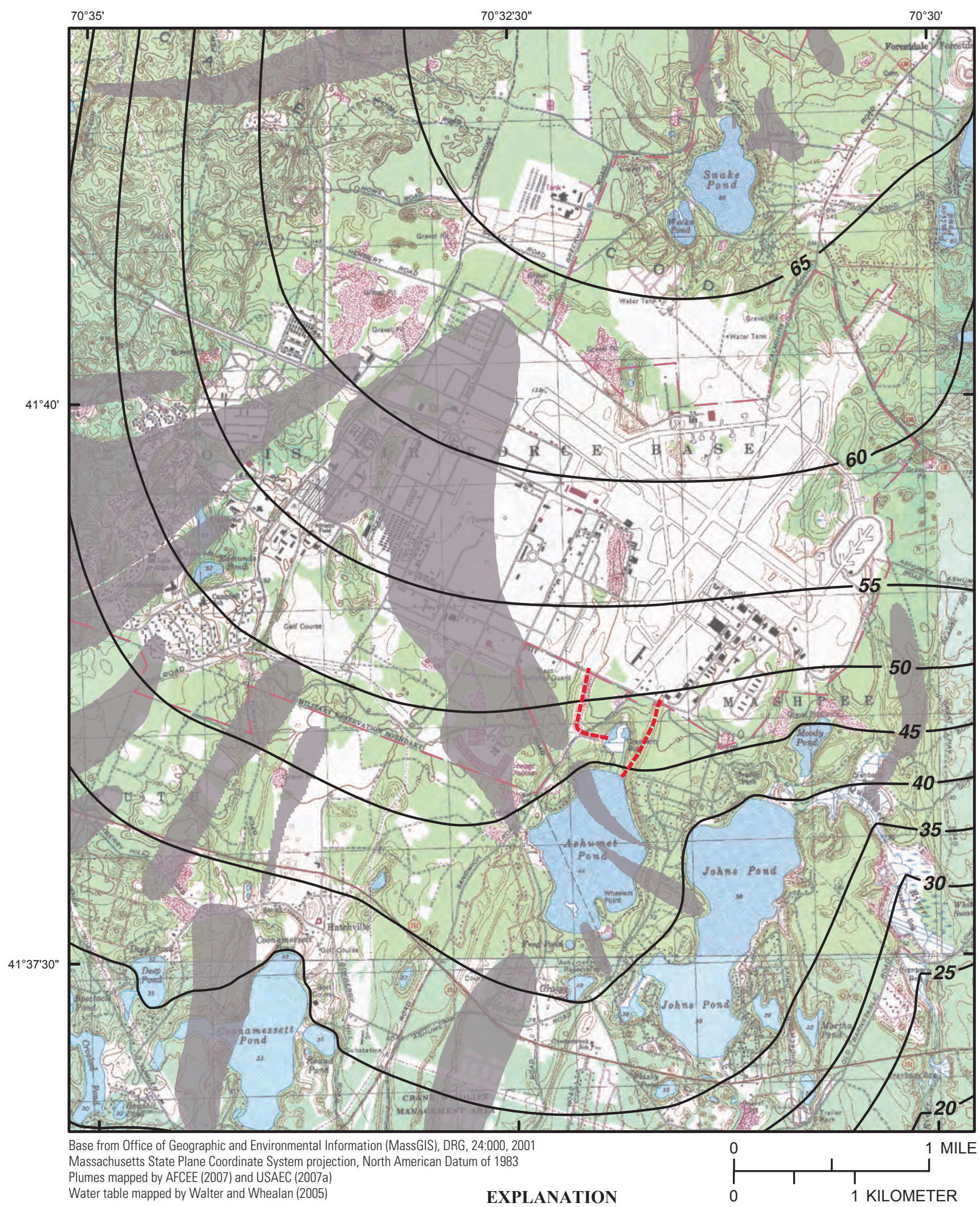

\footnotetext{
Areal extent of plumes of ground-water contamination, 2007

- 50 - Water-table contour - altitude of water table. Contour interval is 5 feet. Datum is NGVD 29

-

—- Boundary of Massachusetts Military Reservation
}

Figure 3. Topographic setting, water-table contours, plumes of ground-water contamination in 2007, and paths of drainage swales from the Massachusetts Military Reservation near Ashumet Pond, Falmouth and Mashpee, Cape Cod, Massachusetts. 
These compounds are in PAH combustion mixtures and serve as good markers for the longer chain carcinogens. The detection limit used for these analyses was fairly high $(220 \mu \mathrm{g} / \mathrm{kg})$ and precluded the detection of most of the carcinogenic PAHs, such as benzo(a)pyrene. These compounds commonly occur at lower concentrations than this limit, although benzo(b)fluoranthene, a known carcinogen, was detected at $270 \mu \mathrm{g} / \mathrm{kg}$. The PAH levels measured in the sediments from Ashumet Pond, however, were substantially lower than the levels measured at USEPA-designated "Area of Concern" sites where livertumor epizootics have been identified (such as the Black and Cuyahoga Rivers in Ohio); at these sites, concentrations of these three compounds were measured at levels of $3,500-109,000 \mu \mathrm{g} / \mathrm{kg}$ (Paul C. Baumann, U.S. Geological Survey, unpublished files, 2007).

Several ground-water contaminant plumes from the MMR were known to discharge to Ashumet Pond at the time of this study (2002). Part of the Chemical Spill 10 plume, which contained trichloroethene (TCE) at concentrations near the lake as high as $1,962 \mu \mathrm{g} / \mathrm{L}$ in 1999 , was believed to be discharging to the northwestern part of the lake (AFCEE, 2000). Similarly, parts of the Ashumet Valley plume, which contained tetrachloroethene (PCE) concentrations as high as $14.6 \mu \mathrm{g} / \mathrm{L}$ in 2002 (AFCEE, 2003) and various contaminants associated with treated municipal wastewater (Walter and others, 1996; McCobb and others, 2003), also was discharging to the lake. Both TCE and PCE have recently been designated as animal carcinogens and probable human carcinogens by the International Agency for Research on Cancer (IARC, 1997). Concentrations of TCE and PCE are diluted rapidly as ground water mixes with the lake water, and these compounds generally are not detectable in the lake water at the discharge locations (AFCEE, 1999). Both plumes continue to discharge to the lake, but at increasingly lower concentrations because of ongoing ground-water remediation. No information is available on contaminants that may have discharged to the lake prior to about 1986, when efforts to identify and characterize the plumes began.

Santuit Pond (fig. 4) also is a ground-water flow-through kettle lake. In addition to ground-water inflow and outflow, Santuit Pond has a surface inlet from an active cranberry bog and surface outlets at its southern end to the Santuit and Little Rivers and a small, unnamed bog. Flow to the streams and bogs is controlled for cranberry production. There is no evidence that contamination from the MMR reaches the lake. Santuit Pond is shallower and smaller than the other two lakes in the study (table 2).

Great Herring Pond (fig. 5) has a surface outlet to the Herring River and a surface inlet at its northern end from a small stream that drains several cranberry bogs and Little Herring Pond. Recreational motorized boating, including the use of personal watercraft vehicles (for example, the Jet Ski), particularly during the summer, is heavier on Great Herring Pond than on the other two lakes in the study (Stephen T. Hurley, MADFW, Southeast Region, unpublished files, December 2007). Contaminants from the MMR cannot reach Great Herring Pond, which is on the mainland side of the Cape Cod Canal.

\section{Field Collection Methods}

Brown bullhead were collected with fyke nets and by electrofishing. The fyke nets had D-shaped first hoops with openings of $0.6-0.76 \mathrm{~m}$, mesh with 12 - or 25 -mm openings when stretched, and leads 9-15 m long. Each afternoon, 6-16 nets were placed near shore with leads attached to posts driven at locations suggested by the MADFW crew on the basis of their knowledge of the lake or in places with habitat known to be favored by bullhead. All nets were fished overnight and sampled by afternoon of the next day. Electrofishing was done by the MADFW with a pulsed direct-current electrofishing boat (Smith-Root, Inc., Model GPP Electrofisher). The sampling dates and numbers of fish caught and examined for each lake are summarized in table 3. Brown bullhead with a minimum length of $250 \mathrm{~mm}$ (selected to maximize the number of fish of age 3 and older) were kept for examination. The first 20-24 fish captured were taken as a necropsy subsample and transported from the collection site to a field laboratory in water-filled coolers. The longest transportation time was 30 minutes. Brown bullhead continued to be caught and processed daily until about 60 fish had been collected from each lake. If insufficient time was available to examine all fish that had been caught in a day, the fish were held in cages in the lake where they had been captured until the examination could be finished.

Table 3. Numbers of brown bullhead (Ameiurus nebulosus) sampled by location and date from Ashumet, Santuit, and Great Herring Ponds, southeastern Massachusetts, May-July 2002.

\begin{tabular}{llccc}
\hline \multicolumn{1}{c}{ Location } & Date sampled (2002) & $\begin{array}{c}\text { Number of fish, } \\
\text { necropsy and field exam }\end{array}$ & $\begin{array}{c}\text { Number of fish, } \\
\text { field exam only }\end{array}$ & $\begin{array}{c}\text { Total number of } \\
\text { fish sampled }\end{array}$ \\
\hline Ashumet Pond & May 21-22, June 7 & 24 & 34 & 58 \\
Santuit Pond & June 25-28, July 1 & 20 & 39 & 59 \\
Great Herring Pond & June 4-7, June 24-26 & 20 & 50 & 70 \\
\hline
\end{tabular}




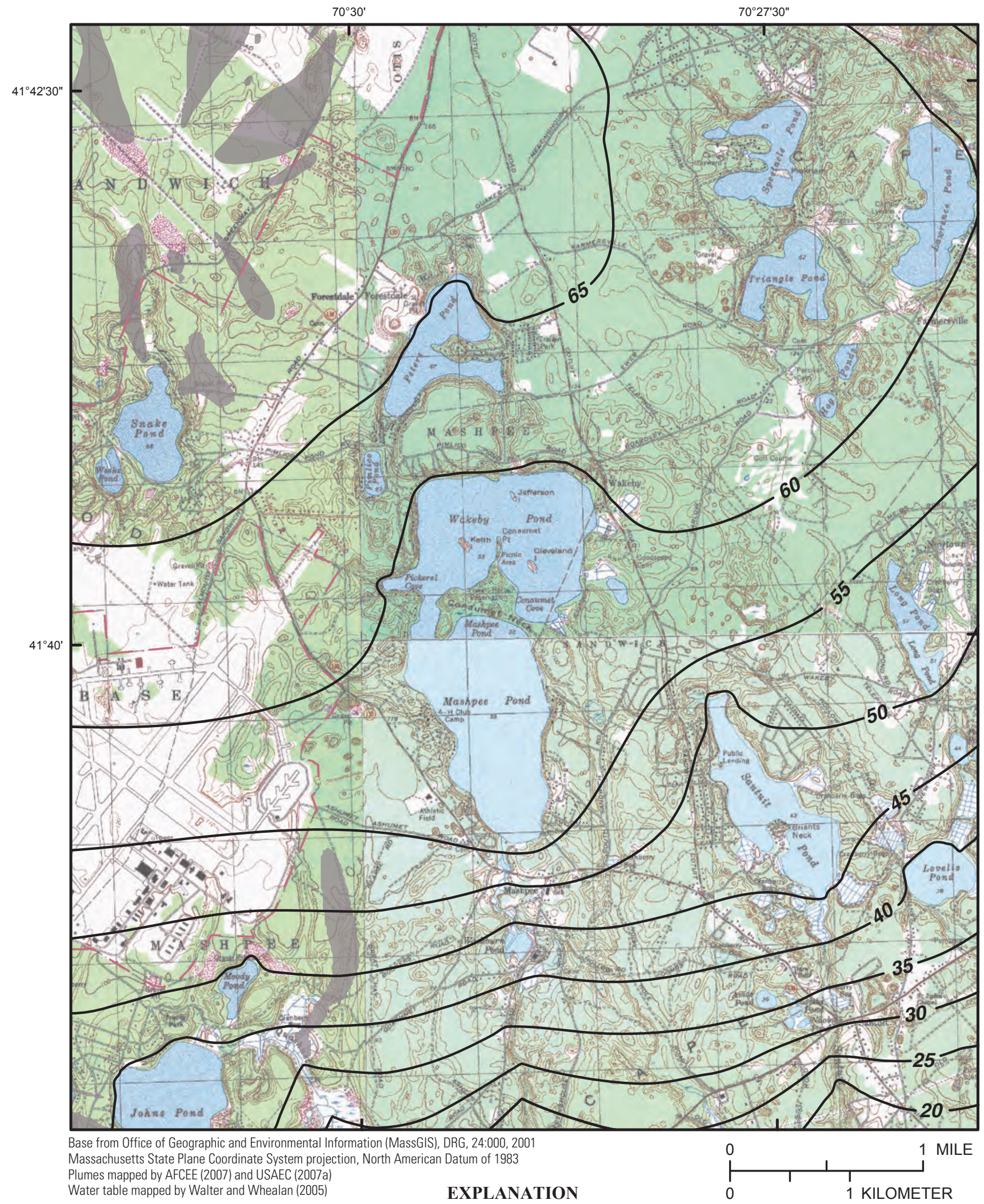

Figure 4. Topographic setting, water-table contours, and plumes of ground-water contamination from the Massachusetts Military Reservation in 2007 near Santuit Pond, Barnstable, Cape Cod, Massachusetts. 


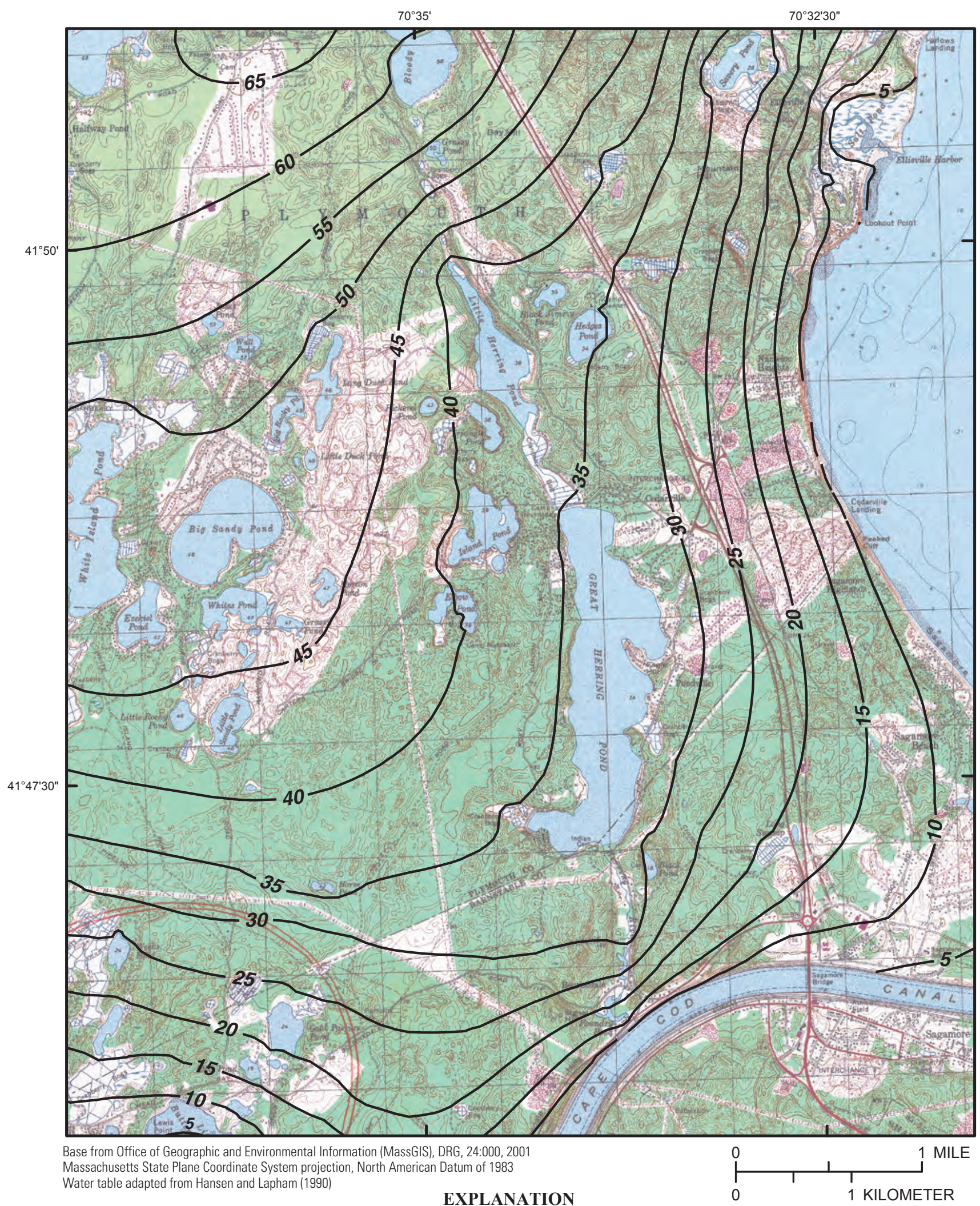

-50- Water-table contour - altitude of water table. Contour interval is 5 feet. Datum is NGVD 29

Figure 5. Topographic setting, water-table contours, and the sea-level Cape Cod Canal near Great Herring Pond, Plymouth, southeastern Massachusetts. 


\section{External Examination, Blood Sampling, and Necropsy}

Fish were processed on site at the lake in several steps. The lengths of the fish were measured, raised lesions on the body surface and in the oral cavity (fig. 6) were counted and measured, and the positions of the lesions were recorded. Areas of nonraised melanistic spotting were also recorded. Abnormal barbels were classified into one of three categories: missing, shortened, or knobbed. Open lesions, melanistic patches, and eye abnormalities also were described. Gender was not recorded for fish processed at the lake. All fish not to be subsampled for necropsy were finclipped for identification and released at their collection site.

At the field laboratory, fish from the necropsy subsample were anesthetized with tricaine methane sulfonate (MS-222), measured (total length), and weighed. Mixed arteriovenous blood was drawn from the caudal artery and vein by using the lateral approach described by Schmitt and others (1999). A heparinized vacutainer tube was used to collect a small amount of blood (less than $0.5 \mathrm{~mL}$ ). This blood was stored on ice and shipped overnight in ice-containing coolers to the USEPA Ecological Exposure Research Division of the National Exposure Research Laboratory in Cincinnati, Ohio. The blood was then processed within 24 hours through the slide-storage step until later analysis was done by using the Comet assay (Tice, 1995). Two blood smears were also made immediately on site.

After the blood was sampled, the fish were euthanized by cervical dislocation. Each individual was inspected for grossly observable lesions involving the skin, eyes, and tissues within the oral cavity by following the same procedure used in the field. Visible abnormalities, including the number of each type of barbel abnormality (nasal, maxillary, and chin), were recorded. Raised lesions were counted, and the prevalence was calculated. Fish were then necropsied. An incision was made in the abdomen from the anus to the isthmus, and the viscera were examined for lesions. Any abnormalities or unusual features that were grossly visible were noted, and a subsample was preserved for histopathology. The sex of the fish was determined and recorded. The liver and spleen were excised, examined, and weighed. Any visible lesions were recorded, and the organs were immediately preserved in 10-percent neutral-buffered formalin for histopathology. Pieces about
$2 \mathrm{~cm}$ in size of the trunk kidney were also removed and placed in formalin for histopathology, as were any gross lesions noted on any other tissues. For brown bullhead from Ashumet Pond, a subsample of barbels and gills was preserved. One pectoral spine was removed whole for later determination of fish age in the laboratory.

\section{Histopathology}

Preparation of tissues for histopathology followed standard procedures currently on file at the Fish Health Branch of the USGS Leetown Science Center, Kearneysville, W.V. Tissue sections were processed and stained with hematoxylin and eosin. In addition, all liver, spleen, and kidney sections were stained with Perl's Prussian blue stain, and selected slides were stained with von Kossa and Giemsa stains (Luna, 1992). Light-microscope observations of bile duct hyperplasia (increased number of bile ducts), altered foci (areas that have altered staining characteristics and are generally accepted as preneoplastic), neoplasia, parasites, granulomas (a specific type of chronic inflammation), multinucleate giant cells (a characteristic of some chronic inflammatory reactions), and thickening of the serosa (lining of the liver) were scored as present or absent. Macrophage aggregate scoring used a severity scale of 0 (none), 1 (mildly scattered), 2 (moderate), and 3 (severe). Tissue slides were archived at the Fish Health Branch.

\section{Age Estimation}

Spines were sectioned near the base, and ages were estimated by two experienced technicians. If their independent estimates did not agree, both technicians reexamined the cross sections in question to reach an age estimate by consensus. The overall percent agreement between technicians was 80 percent, which is high for age estimates from spine cross sections. Age estimates that seemed low for the size of the fish were redetermined by using a variable-setting fiber-optic light source, which allowed the use of higher intensity light to look for annuli near the spine edge. Of 12 fish from two sites that were reexamined, the second age estimate agreed with the first for 8 fish. Of the other 4 fish, all from Ashumet Pond, the age was increased by 1 year ( 2 fish), 2 years ( 1 fish), and 3 years (1 fish). 

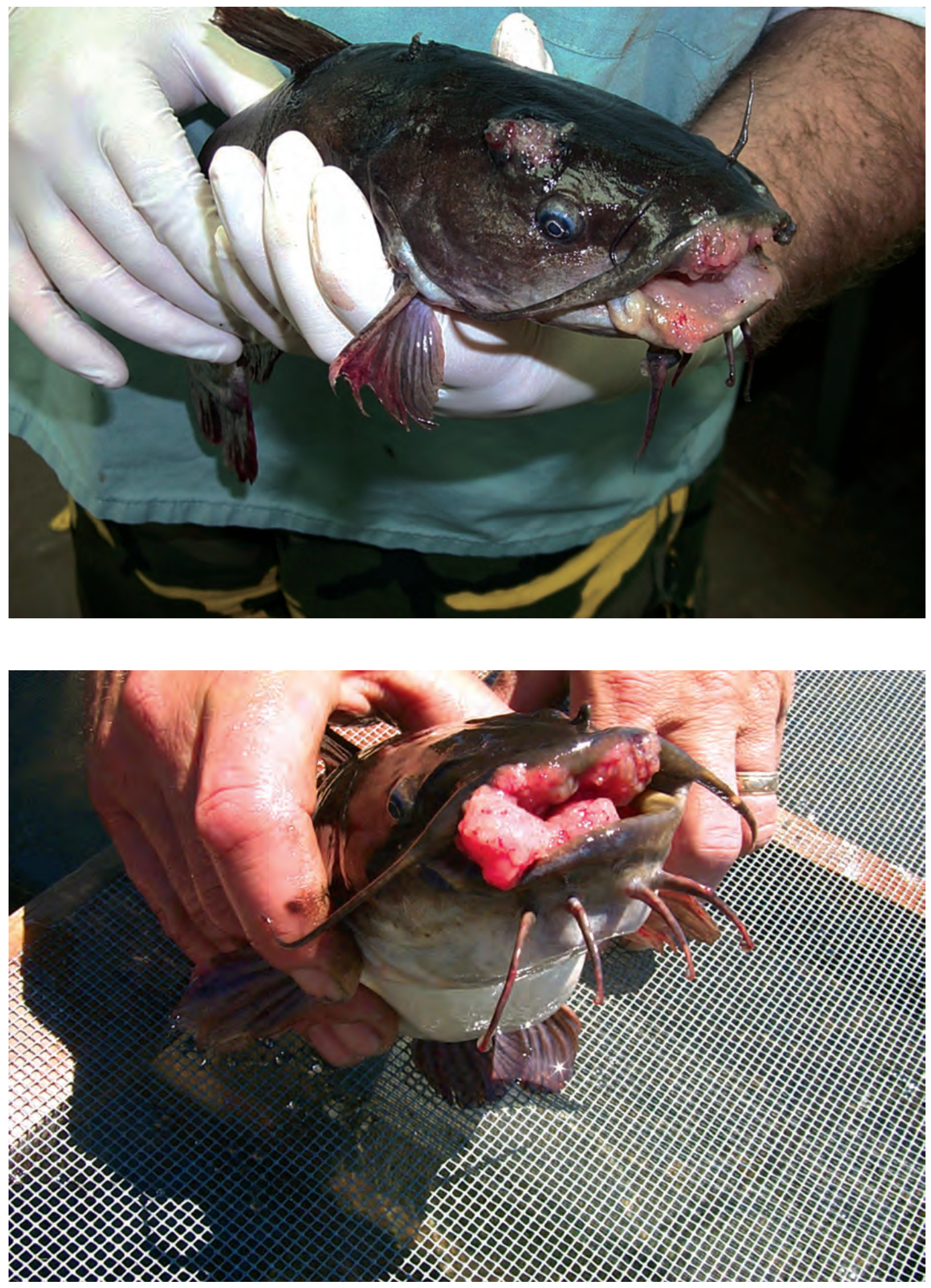

Figure 6. Two examples of brown bullhead (Ameiurus nebulosus) from Ashumet Pond, Cape Cod, Massachusetts, with body-surface and oral lesions and shortened barbels, May 2002. 


\section{Blood Analysis by Comet Assays}

The single-cell gel electrophoresis, also called the "Comet" assay, is a method that measures deoxyribonucleic acid (DNA) damage at the individual cell level by analysis of DNA migration in gel-embedded cells following electrophoresis (Singh and others, 1988). The name "Comet" refers to the formation of a long comet-like tail of DNA fragments as a result of DNA damage (fig. 7). This assay has been used as an indicator of DNA damage in wild fish from sites contaminated with a variety of compounds, including PAHs, polychlorinated biphenyls (PCBs), and heavy metals (Chang and others, 2005; Devaux and others, 1998; Winter and others, 2004; Yang and others, 2006). Because of funding constraints, blood samples from fish caught only in Ashumet and Great Herring Ponds were analyzed with this method.

The Comet assay was performed as described by Singh and others (1988) and modified by Tice (1995). To explain briefly, $3 \mu \mathrm{L}$ of fish blood were diluted with $1 \mathrm{~mL}$ of cold mincing solution. Then $10 \mu \mathrm{L}$ (in duplicate) of the diluted blood were mixed with $75 \mu \mathrm{L}$ of 0.5 -percent low-melting agarose (LMA) at $37^{\circ} \mathrm{C}$ and pipetted onto a microscope slide precoated with a layer of 1.2-percent normal-melting agarose. The slides were cooled on ice until the agarose layer hardened; then another layer of LMA was added, and the slides were cooled on ice again. Next the slides were placed overnight in cold (about $4^{\circ} \mathrm{C}$ ) lysing solution. This step was followed by placement in alkaline electrophoresis buffer ( $\mathrm{pH}$ greater than 13) for 15 minutes to allow for unwinding of the DNA. Electrophoresis was then run for 10 minutes $(25 \mathrm{~V}, 265 \mathrm{~mA})$ at room temperature. After electrophoresis, the slides were neutralized, fixed by immersion in cold methanol, air-dried, and stored at room temperature.

The slides were stained with ethidium bromide and were scored on a fluorescent microscope at 400X magnification by using Comet image-analysis software (Komet 4.0, Kinetic Imaging, Liverpool, United Kingdom). The Comet parameters that were analyzed for each cell included the length of DNA migration (tail length, in micrometers), the percentage of migrated DNA (percentage of DNA in the tail relative to total DNA in the image), and the tail-extent moment (calculated as the tail length multiplied by the percentage of DNA in the tail). Fifty cells per slide and a total of 100 cells per fish were analyzed to evaluate the extent of DNA damage for each fish.

\section{Statistical Methods}

Tukey's studentized range test was used to compare fish length and hepatosomatic index (HSI) among fish from the different lakes. The chi-square test, or Fisher's exact test when sample-size conditions of the chi-square test were not met, was used to compare the prevalences of lesions and barbel abnormalities among fish caught in different locations. For
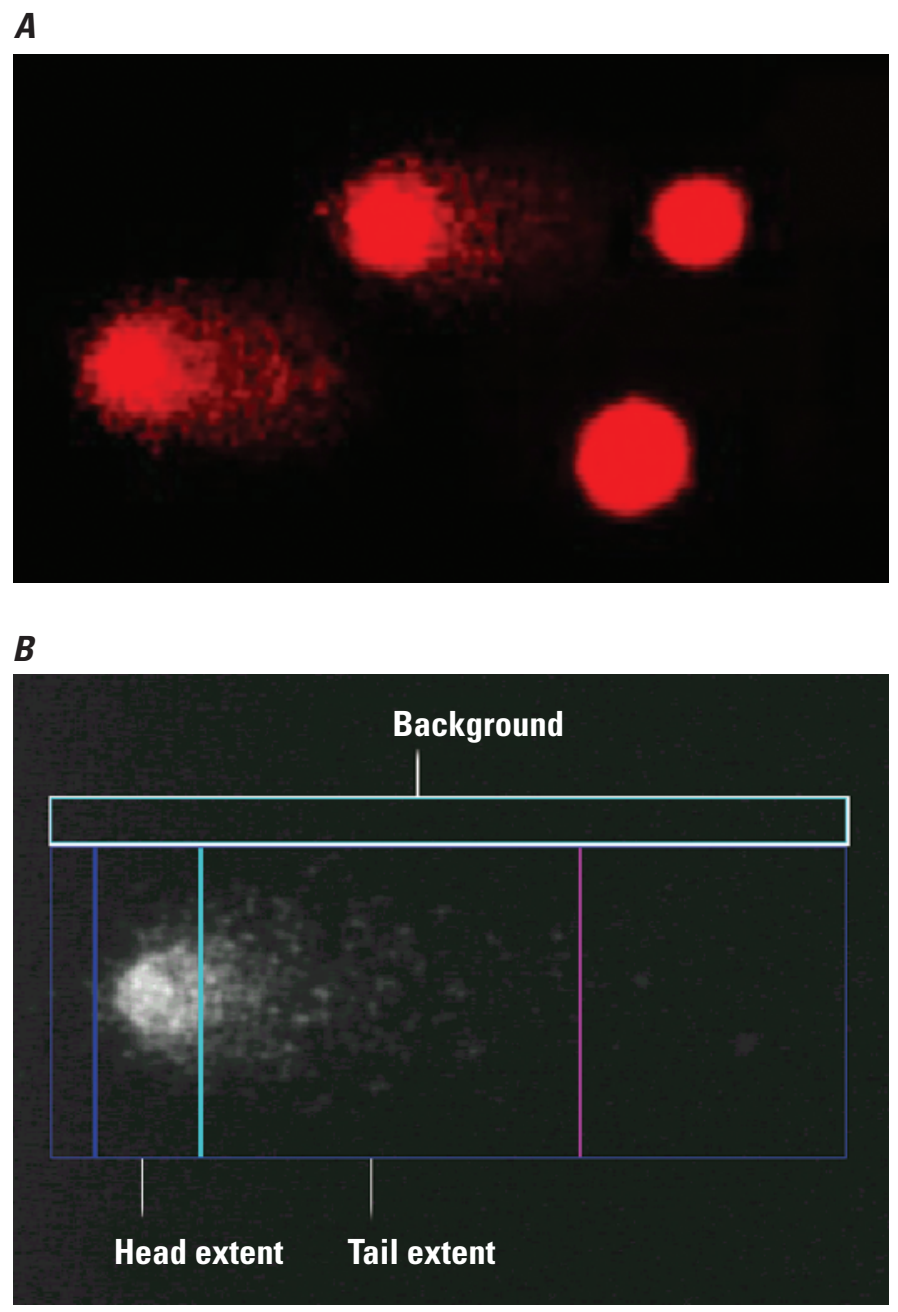

Figure 7. Images of Comet assays showing $(A)$ assay of blood sample from a Cape Cod, Massachusetts, brown bullhead (Ameiurus nebulosus) and (B) interpretation of a typical assay.

the Comet assay, statistical analyses were performed by using SAS version 8.1 software (SAS Institute, Inc., Cary, N.C.). The general linear model (GLM) included the variables sampling site (contaminated versus reference), fish gender (female versus male), and length (as a measure of age). This method of analysis was used to detect whether the extent of DNA damage measured by the Comet assay (tail length, percent tail DNA, tail-extent moment) was affected by these variables. Logistic regression models were developed to examine the relationship between the probability of lesion or deformity occurrence and DNA damage measured by the Comet assay. 


\section{Prevalence of Tumors in Brown Bullhead}

The prevalence of tumors was determined from the examination of 187 brown bullhead collected in spring 2002 from Ashumet, Santuit, and Great Herring Ponds (table 3). Selected data from the field examination of the fish are reported in appendix 1. The combination of fyke nets and electrofishing resulted in complete or nearly complete samples from the three lakes. The histopathology of the skin, body tumors, and liver tissue and the genetic damage to red blood cells were determined from subsamples collected from the 64 necropsied brown bullhead from the lakes. Selected data from the laboratory examination of the necropsied fish are reported in appendix 2.

\section{Size and Age Distributions}

The distributions of brown bullhead lengths differed among the three lakes. Brown bullhead from Ashumet Pond were largest in average size $(379 \mathrm{~mm})$, and those from Santuit Pond were significantly ( $\alpha=0.05$, Tukey's studentized range test) shorter $(286 \mathrm{~mm})$ than fish from either Great Herring Pond (336 mm) or Ashumet Pond (appendix 1). The size difference between the brown bullhead specimens from Santuit and Ashumet Ponds was great enough that the range overlapped for only 3 fish (1 from Santuit Pond and 2 from Ashumet Pond) of the 117 fish sampled. Fish from Great Herring Pond were closer in size to fish from Ashumet Pond but were still significantly smaller $(\alpha=0.05$, Tukey's studentized range test).

Ages were obtained only for the fish that were necropsied (appendix 2). Brown bullhead from Ashumet Pond were older on average than those from either of the other lakes. One-third of the fish from Ashumet Pond were age 7 or older, whereas only one-fifth or fewer of brown bullhead from the other lakes reached that age. The ages of insufficient numbers of fish were obtained to permit determination of age-specific lesion frequencies. Also, only spines were used for aging, and these have recently been shown to underestimate the true age of fish, particularly at year 5 and older (Maceina and Sammons, 2006).

\section{Prevalence of External Raised Lesions}

The prevalences of body-surface, oral, and total external raised lesions, presumed by field observation to be tumors, were dependent on location (chi-square test, $p<0.0001$ ) (table 4). Fish from Ashumet Pond had the highest prevalence, and fish from Great Herring Pond had the lowest prevalence. Fish from Great Herring Pond had a prevalence of total
Table 4. Percentage by location of brown bullhead (Ameiurus nebulosus) having external raised lesions, Ashumet, Santuit, and Great Herring Ponds, southeastern Massachusetts, MayJuly 2002.

\begin{tabular}{lccc}
\hline \multicolumn{1}{c}{ Location } & Oral lesions & $\begin{array}{c}\text { Body-surface } \\
\text { lesions }\end{array}$ & $\begin{array}{c}\text { Total external } \\
\text { lesions }\end{array}$ \\
\hline Ashumet Pond & 46.6 & 48.3 & 62.1 \\
Santuit Pond & 28.8 & 20.3 & 48.3 \\
Great Herring Pond & 0 & 2.8 & 2.8 \\
\hline
\end{tabular}

external raised lesions that was less than 3 percent (table 4). Prevalences of oral and body-surface lesions in brown bullhead from Santuit Pond were each about one-half of that in brown bullhead from Ashumet Pond, although the prevalences of total external lesions in the two lakes were similar. The prevalence of large, raised lesions also differed between Ashumet and Santuit Pond fish (fig. 8). A greater percentage of fish had large (greater than $6 \mathrm{~mm}$ ) oral and body-surface lesions in Ashumet Pond. If medium and large oral lesions were grouped (all lesions $3 \mathrm{~mm}$ or larger), they were observed on 33.8 percent of brown bullhead from Santuit Pond but on 56.9 percent of brown bullhead from Ashumet Pond. Similarly, medium and large body-surface lesions (3 mm or larger) were observed on 22.1 percent of Santuit Pond fish but on 70.6 percent of Ashumet Pond fish.

The percentage of fish having single and multiple lesions also differed by location. The prevalence of single external lesions was significantly different on fish from the three lakes (chi-square test, $p=0.0443$ ), although the prevalence of single lesions was similar for fish from Santuit and Ashumet Ponds; fish from Great Herring Pond had a significantly lower prevalence of single lesions than did the fish from the other two lakes. The occurrence of multiple lesions also was significantly different on fish from the three lakes (chi-square test, $p<0.0001$ ) (fig. 9). Multiple lesions were observed almost twice as often on fish from Ashumet Pond as on fish from Santuit Pond and were not found on any fish from Great Herring Pond. Similarly, melanistic patches - abnormally darkened, but not raised, areas of skin — were absent on fish from Santuit Pond but were observed on almost 70 percent of the fish from Ashumet Pond (fig. 9). Melanistic patches on brown bullhead from Great Herring Pond had less than 10 percent prevalence, significantly lower than on fish in Ashumet Pond (chi-square test, $p<0.0001$ ). 


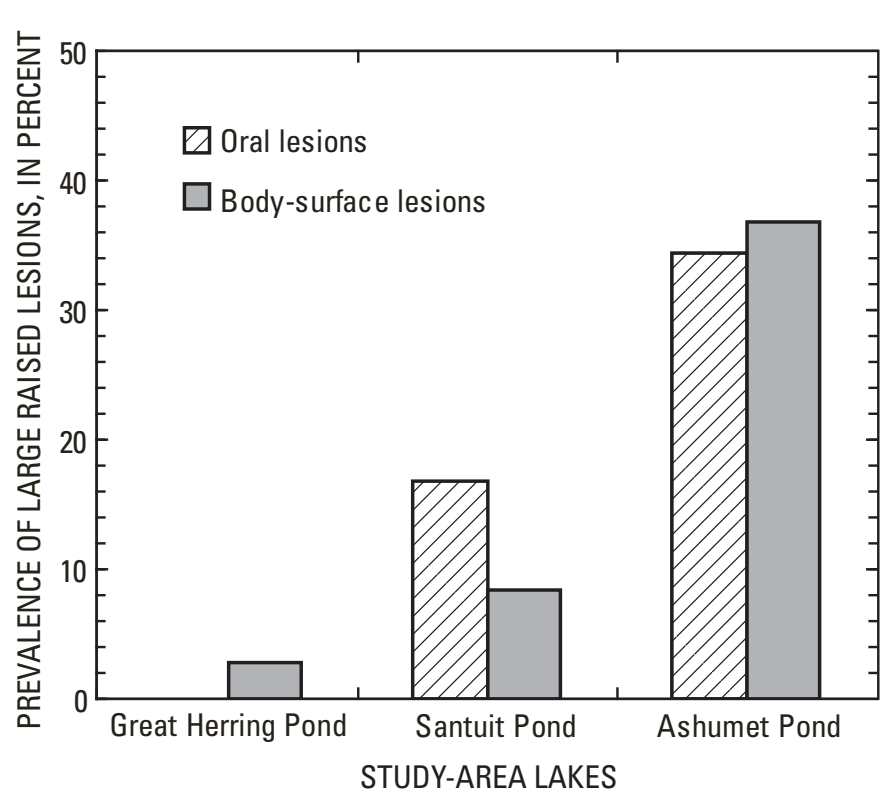

Figure 8. Prevalences of large (greater than 6 millimeters) raised oral and body-surface lesions in brown bullhead (Ameiurus nebulosus) from Great Herring, Santuit, and Ashumet Ponds, Cape Cod, Massachusetts, May-July 2002.

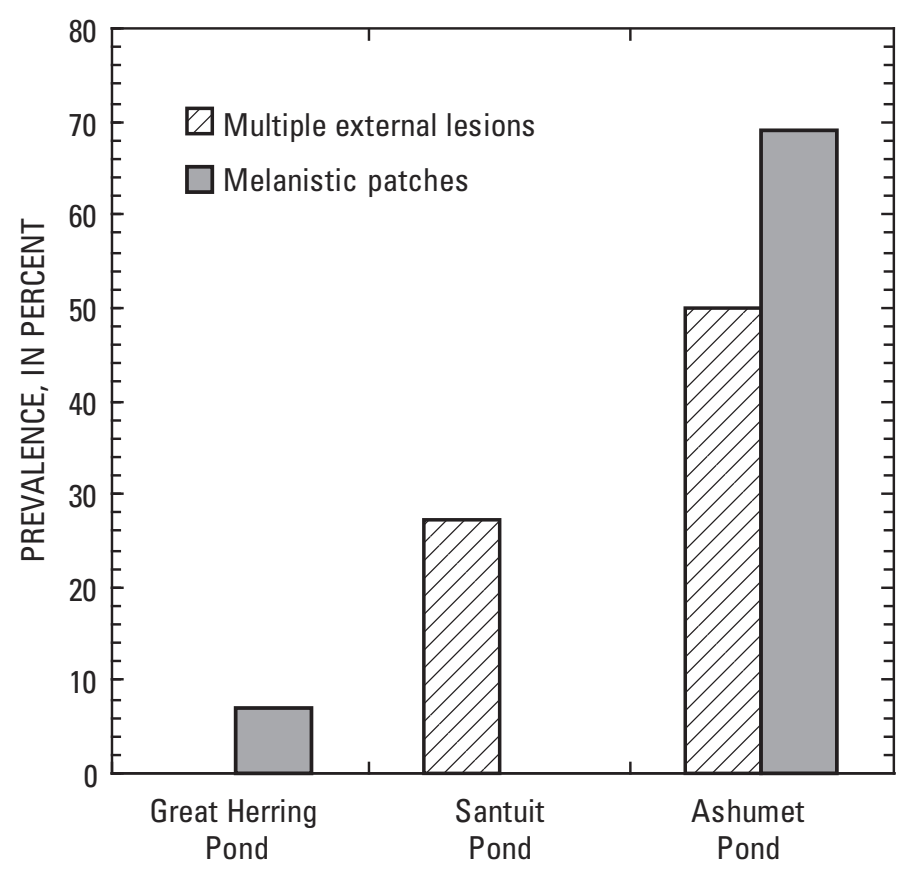

STUDY-AREA LAKES

Figure 9. Prevalences of multiple external lesions and melanistic patches in brown bullhead (Ameiurus nebulosus) from Great Herring, Santuit, and Ashumet Ponds, Cape Cod, Massachusetts, May-July 2002.

\section{Prevalence of Barbel Deformities}

Fish from Santuit Pond had the highest prevalence of missing barbels, whereas fish from Ashumet Pond had the lowest prevalence (table 5). This difference was significant at the $p<0.05$ level (chi-square test, $p=0.0378$ ). The frequency of shortened barbels was similar among fish from the three lakes. Whereas fish from Ashumet Pond had at least twice the prevalence of knobbed barbels as fish from the other lakes, the prevalences were not significantly different (chi-square test, $p=0.0496$ ). A comparison of total barbel lesions on fish from the three lakes did not indicate any significant differences (chi-square test, $p=0.1843$ ).

\section{Histopathology of External Lesions}

Of the 24 necropsied fish collected from Ashumet Pond, 10 fish were reported by gross observation to have raised body-surface lesions. Samples of lesions from six of the fish were submitted for histopathology. One lesion was a nonneoplastic (hyperplastic) lesion of epidermal thickening (fig. 10A), two were squamous cell carcinomas, and three were papillomas (fig. 10B). Thirteen of the necropsied fish were reported by gross observation to have raised lesions in the oral cavity. Pieces of eight of these lesions were taken for histopathology. Three of the eight lesions were papillomas, and five were squamous cell carcinomas (fig. 10C). Thus, of the 14 lesions collected from fish from Ashumet Pond (diagnosed by gross observation as tumors) and fixed for histopathology, 13 lesions (or 93 percent) were verified as neoplasia.

At Santuit Pond, 8 of the 20 necropsied fish were reported by gross observation to have raised body-surface or oral tumors; two samples were submitted for histopathology. Both were diagnosed as papillomas. At Great Herring Pond, two fish were reported to have raised lesions; however, samples were not taken from either fish.

Table 5. Percentage by location of brown bullhead (Ameiurus nebulosus) having barbel abnormalities, including missing, shortened, and knobbed barbels, Ashumet, Santuit, and Great Herring Ponds, southeastern Massachusetts, May-July 2002.

\begin{tabular}{lccc}
\hline \multicolumn{1}{c}{ Location } & $\begin{array}{c}\text { Missing } \\
\text { barbels }\end{array}$ & $\begin{array}{c}\text { Shortened } \\
\text { barbels }\end{array}$ & $\begin{array}{c}\text { Knobbed } \\
\text { barbels }\end{array}$ \\
\hline Ashumet Pond & 6.9 & 22.4 & 22.4 \\
Santuit Pond & 23.7 & 28.8 & 10.2 \\
Great Herring Pond & 14.3 & 20.0 & 8.6 \\
\hline
\end{tabular}




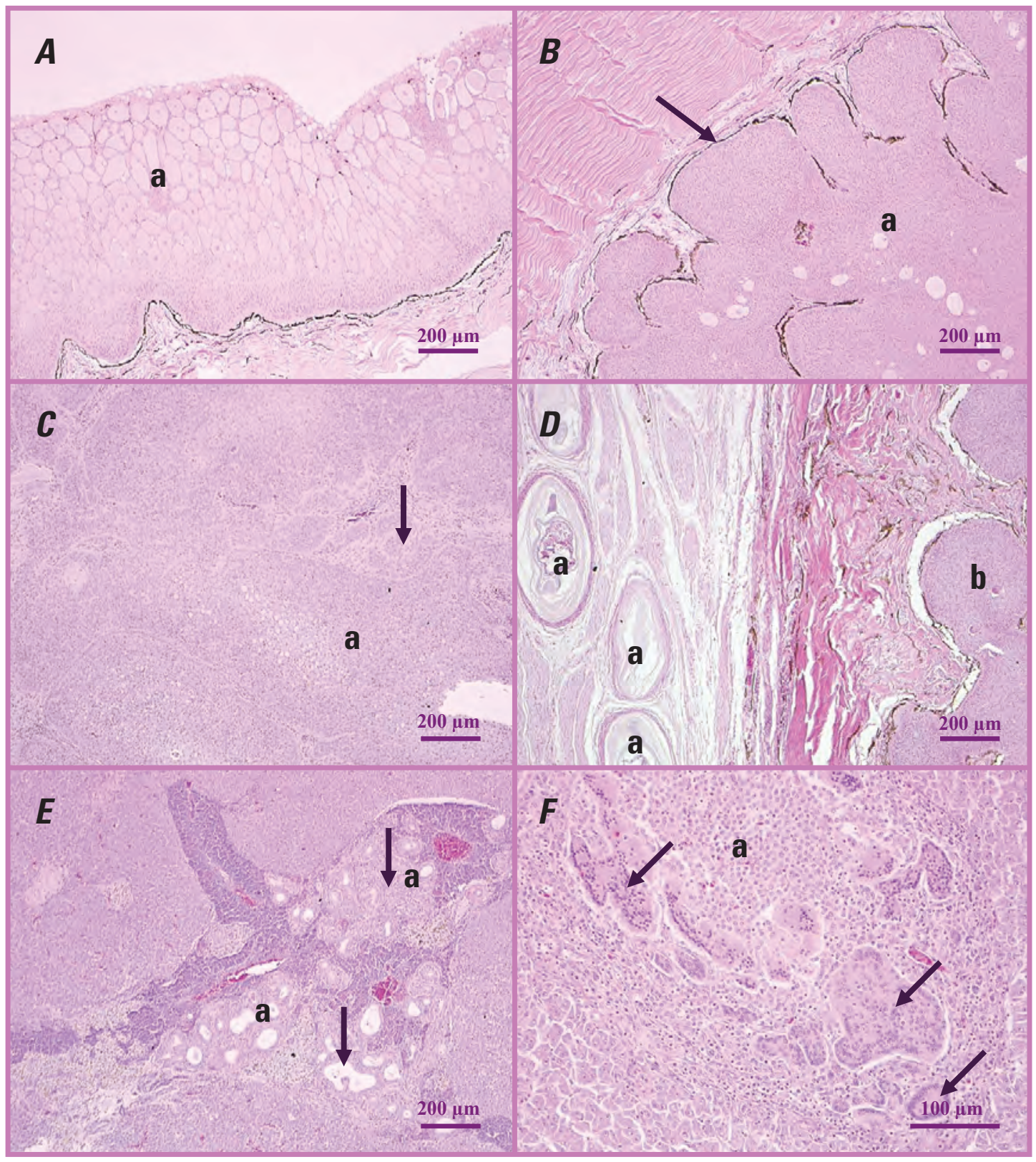

Figure 10. Selected microscopic findings in tissues of brown bullhead (Ameiurus nebulosus) from Ashumet Pond, Cape Cod, Massachusetts, May 2002. (A) Hyperplastic skin lesion with a proliferation of epidermal cells, primarily alarm substance cells (a). (B) Papilloma of the body surface. The proliferating cells (a) do not invade beyond the basement membrane (arrow). (C) Squamous cell carcinoma from the oral cavity. Proliferating cells (a) do invade through the basement membrane, and nests of neoplastic cells can be seen within connective tissue (arrow). (D) Section of a barbel with trematodes (a) within the nerve tissue underlying a papillomatous skin lesion (b). (E) Cholangioma (a) within the liver. Misshapen bile ducts with proliferating epithelium (arrows) are observed but are not invading into the surrounding liver. (F) Area of chronic inflammation (a) and multinucleate giant cells (arrows) within hepatic tissue in response to helminth parasites. Hematoxylin and eosin stain. 
Barbels from fish taken from Ashumet Pond contained metacercariae of digenetic trematodes along and within the nerve bundles (fig. 10D). These organisms were associated with hemorrhage and inflammation within the dermis and along and within the nerve fibers. Papillomas, squamous cell carcinomas, and dysplasia of the pseudocartilage were also observed in the barbels.

\section{Histopathology of the Liver, Spleen, and Kidney}

Regeneration of liver cells, altered cell foci, and neoplasia were all found more often in brown bullhead from Ashumet Pond than from the other two lakes (table 6). Most of the neoplasms were of bile duct origin - cholangioma (benign) or cholangiocarcinoma (malignant) (fig. 10E). One fish collected from Ashumet Pond had a malignant hepatic cell carcinoma, and one fish collected from Santuit Pond had a benign hepatic cell adenoma. Vacuolation of the intrahepatic exocrine pancreas was observed in 25 percent of the fish from

Table 6. Percentage of necropsied brown bullhead (Ameiurus nebulosus) having selected microscopic lesions observed in liver tissue, Ashumet, Santuit, and Great Herring Ponds, southeastern Massachusetts, May-July 2002.

\begin{tabular}{lrrr}
\hline \multicolumn{1}{c}{ Lesion type } & $\begin{array}{c}\text { Ashumet } \\
\text { Pond }\end{array}$ & $\begin{array}{c}\text { Santuit } \\
\text { Pond }\end{array}$ & $\begin{array}{c}\text { Great Herring } \\
\text { Pond }\end{array}$ \\
\hline Liver cell regeneration & 45.8 & 0.0 & 15.0 \\
$\begin{array}{l}\text { Exocrine pancreas } \\
\quad \text { vacuolation }\end{array}$ & 25.0 & .0 & .0 \\
Bile duct hyperplasia & 50.0 & 60.0 & 60.0 \\
Altered cell foci & 37.5 & 25.0 & 15.0 \\
Neoplasia & 16.7 & 15.0 & 5.0 \\
\hline
\end{tabular}

Table 7. Hepatosomatic index (liver weight divided by body weight) of brown bullhead (Ameiurus nebulosus) from Ashumet, Santuit, and Great Herring Ponds, southeastern Massachusetts, May-July 2002.

\begin{tabular}{lccc}
\hline \multicolumn{1}{c}{ Statistic } & Ashumet Pond & Santuit Pond & Great Herring Pond \\
\hline Mean & 0.0242 & 0.0156 & 0.0152 \\
Standard error & .00117 & .00066 & .00078 \\
Maximum & .042 & .022 & .024 \\
Minimum & .016 & .011 & .011 \\
\hline
\end{tabular}

Ashumet Pond but was not observed in fish from the other two lakes. Macrophage aggregates and parasites were observed in fish from all the lakes. The number of macrophage aggregates in the liver, spleen, and kidney did not vary consistently among sites. Heavy infections of immature cestodes were found in almost all fish. Often these parasites were associated with an intense inflammatory response and multinucleate giant cells (fig. 10F). Bile duct myxozoans were found in some fish at every site (37.5 percent at Ashumet Pond, 25 percent at Santuit Pond, and 20 percent at Great Herring Pond) and may be related to bile duct proliferation.

\section{Hepatosomatic Index}

A variety of investigators have noted a positive correlation between exposure to PAHs and the ratio of the liver weight to body weight (hepatosomatic index, or HSI) in fish (Fabacher and Baumann, 1985; Pinkney and others, 2001). The relationship has been most striking at very high levels of PAH contamination, however, and is less obvious for intermediate levels of contamination (such as in Ashumet Pond), where other factors affecting liver size (such as nutrition, disease, and seasonal vitellogenin synthesis) may play a more dominant role (Yang and Baumann, 2006). The HSI was significantly greater for fish from Ashumet Pond than for fish from Great Herring and Santuit Ponds $(\alpha=0.05$, Tukey's studentized range test); the indexes for fish from the latter two lakes had similar HSI values (table 7). The range of values from these sites also indicates that the brown bullhead population in Ashumet Pond had a higher proportionate liver mass (table 7).

\section{DNA Damage in Red Blood Cells}

The Comet assay parameters - tail length, percentage of tail DNA, and tail-extent moment - did not differ significantly with fish length (GLM, $p>0.05)$. Although female and male fish from Ashumet and Great Herring Ponds differed in the percentage of tail DNA (GLM, $p<0.05)$, they did not differ in tail length and tail-extent moment (GLM, $p>0.10$ ). Therefore, the age (with length as a surrogate) and gender of fish did not seem to exert a major effect on the Comet assay results. All three of the measurements of DNA damage were significantly greater in fish from Ashumet Pond than in fish from Great Herring Pond (GLM, $p<0.05$ ) (table 8). For fish from the two ponds, logistic regression analysis demonstrated that the tail length measured in the Comet assay was positively related to the odds ratio of fish having external raised lesions $(\ln [\mathrm{P}(\mathrm{x}) /(1-\mathrm{P}(\mathrm{x}))]=-10.75+0.2322 \times$ tail length, Wald's test, $p<0.05)$. 
Table 8. Red blood cell nucleic DNA damage as determined by the Comet assay for brown bullhead (Ameiurus nebulosus) from Ashumet and Great Herring Ponds, southeastern Massachusetts, May-July 2002.

[Values are means with standard deviation in parentheses. DNA, deoxyribonucleic acid; $\mu \mathrm{m}$, micrometer]

\begin{tabular}{lcccc}
\hline \multicolumn{1}{c}{ Location } & $\begin{array}{c}\text { Number of bullhead } \\
\text { sampled }\end{array}$ & $\begin{array}{c}\text { Tail length of migrated DNA } \\
(\boldsymbol{\mu} \mathbf{m})\end{array}$ & $\begin{array}{c}\text { DNA in tail relative to total } \\
\text { DNA in image } \\
\text { (percent) }\end{array}$ & $\begin{array}{c}\text { Tail-extent moment } \\
(\boldsymbol{\mu m})\end{array}$ \\
\hline Ashumet Pond & 10 & $46.95(3.11)$ & $19.22(1.90)$ & $10.27(1.34)$ \\
Great Herring Pond & 11 & $40.89(2.90)$ & $15.28(1.64)$ & $7.06(1.03)$ \\
\hline
\end{tabular}

\section{Discussion}

External raised lesions were significantly more common in brown bullhead from Ashumet and Santuit Ponds than in brown bullhead from Great Herring Pond (table 4). Ashumet Pond was the primary target site because previous fish surveys had found an unusually high prevalence of raised lesions on brown bullhead captured there (HAZWRAP, 1995, 1996; Stegeman, 1997). Great Herring and Santuit Ponds were sampled as reference sites; therefore, the elevated prevalence of raised lesions at Santuit Pond was unexpected. Comparison with the prevalence of raised lesions recorded in fish from Great Lakes locations (fig. 11) indicates that fish from both Ashumet and Santuit Ponds are at the high end of the range of raised-lesion prevalence seen in fish from contaminated locations, with prevalences close to the levels of occurrence documented in fish collected in Hamilton Harbour, Ontario, Canada (Smith and others, 1989) in the mid-1980s and in Presque Isle Bay, Penn. (Obert, 1994) in the early 1990s. Similarly, brown bullhead from Great Herring Pond mimic the raised-lesion prevalence between 2 and 4 percent seen in fish from Great Lakes reference locations (fig. 11). Of the 16 external raised lesions submitted for histopathology from Ashumet and Santuit Ponds fish, 15 (or 94 percent) were diagnosed as neoplasms. This result provides a level of confidence for the comparison in figure 11.

Fish age is correlated with the prevalences of both internal tumors (Baumann and others, 1990; Pinkney and others, 2004) and external raised lesions (Maccubbin and Ersing, 1991; Pinkney and others, 2004). Thus, tumor prevalences are best compared among fish of the same or similar age groups. The estimated ages of some fish from both Ashumet Pond and Great Herring Pond were only 3 or 4 years, despite the fact that the fish were very large. These data may indicate that the age was underestimated, as compression and loss of annuli are a well-documented problem in determining the ages of older fish by examination of spines. Future studies should collect otoliths as well as spines for aging. Nevertheless, the order-ofmagnitude difference in the prevalence of raised lesions and the levels of significance achieved because of the numbers of fish examined in this study leave no doubt that external raised lesions are much more common in brown bullhead from both Ashumet and Santuit Ponds than would be expected.

The prevalences of shortened and knobbed barbels were not significantly different in fish collected from the three lakes. Fish from Santuit Pond had the highest occurrence of missing barbels; of the three barbel anomalies, however, this abnormality is the least connected with chemical exposure and often results from physical stress. Therefore, barbel deformities were not useful in characterizing potential contaminant exposure among fish in these lakes.

The histopathology of the liver, although done by using a small number of fish from each location ( $\mathrm{N}=20$ to 24), showed a prevalence of neoplasms (mainly of bile duct origin) 15 percent or higher for both Ashumet and Santuit Ponds. This prevalence is comparable to prevalences measured in fish from a number of Great Lakes Areas of Concern with contaminantrelated tumor epizootics and is greater than the 5-percent prevalence level thought to indicate a reference condition (Baumann and others, 1996). Because the only known cause of liver tumors in fish is chemical carcinogens, these data, combined with the external-tumor data, indicate a role for carcinogenic contaminants in the tumor pathology of brown bullhead in Ashumet and Santuit Ponds.

The Comet assay was used to quantify genetic damage and provide an index of exposure to tumor-inducing chemicals in the brown bullhead population. This method can be used with any age class of fish and provides a measure of genetic damage at the time of animal capture. Logistic regression indicated that higher DNA damage measured by the Comet assay was associated with higher prevalence of external lesions. The results also indicated that DNA damage was greater in brown bullhead from Ashumet Pond than in bullhead from Great Herring Pond (table 8). The data from the present study, along with a previous analysis of brown bullhead collected at four other locations (tributaries to Lake Erie), indicate that DNA damage does not differ significantly with fish length (Yang and others, 2006). This observation indicates that the greater DNA damage observed in brown bullhead from Ashumet Pond than in bullhead from Great Herring Pond is not confounded by differences in the ages of fish collected at the two locations. 


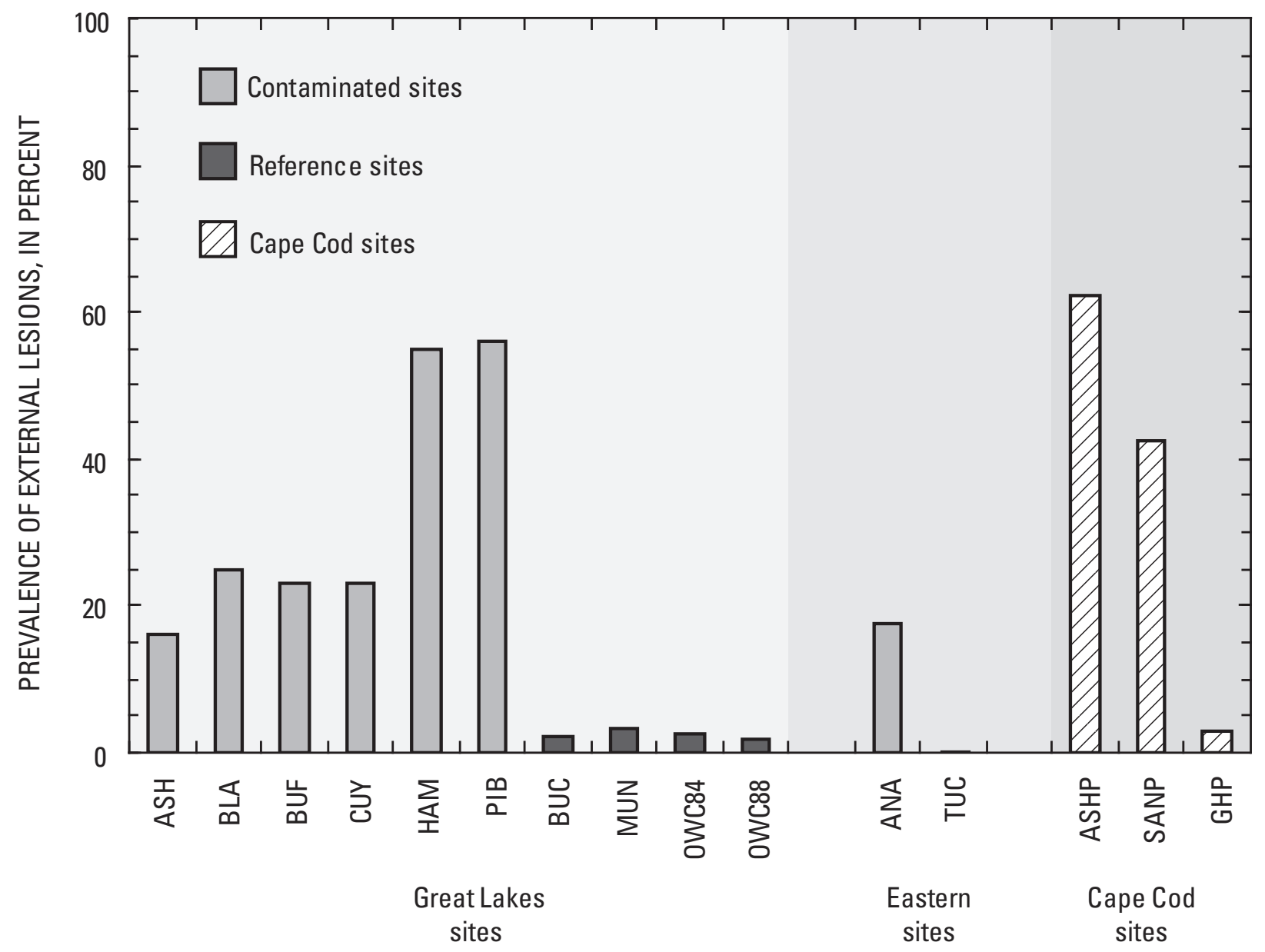

Figure 11. Prevalence of raised external lesions in brown bullhead (Ameiurus nebulosus) from tributaries of the Great Lakes, rivers in the eastern United States and Canada, and Ashumet, Santuit, and Great Herring Ponds on Cape Cod, Massachusetts. Sample sizes ranged from 48 to 179 fish, with a mean sample size of more than 100 fish per location. ASH, Ashtabula River, Ohio (Mueller and Mac, 1994); BLA, Black River, Ohio (Baumann and others, 1996); BUF, Buffalo River, New York (Baumann and others, 1996); CUY, Cuyahoga River, Ohio (P.C. Baumann, unpublished data); HAM, Hamilton Harbour, Ontario, Canada (Smith and others, 1989); PIB, Presque Isle Bay, Pennsylvania (Obert, 1994); BUC, Buckeye Lake, Ohio (P.C. Baumann, unpublished data); MUN, Munuscong Bay, Michigan (Baumann and others, 1991); OWC84, Old Woman Creek, Ohio, 1984-85 (Baumann and others, 1996); OWC88, Old Woman Creek, Ohio, 1988 (P.C. Baumann, unpublished data); ANA, Anacostia River, Washington, D.C. (Pinkney and others, 2004); TUC, Tuckahoe River, Maryland (Pinkney and others, 2004); ASHP, Ashumet Pond; SANP, Santuit Pond; GHP, Great Herring Pond. 
These results imply that fish from Ashumet Pond may have been exposed to higher levels of genotoxins than have fish from Great Herring Pond.

Several studies employing the Comet assay have examined the relation between the extent of induced DNA damage and the time elapsed after the treatment of fish with genotoxic chemicals. Pandrangi and others (1995) reported increased damage to erythrocytes (red blood cells) from brown bullhead within 6 hours following a single intraperitoneal injection of cyclophosphamide; the response peaked at 48-72 hours. Belpaeme and others (1998) observed increased DNA damage to erythrocytes in marine flatfish (turbot) (Psetta maximus) exposed by static renewal to ethyl methane sulfonate (EMS) in water; the response in several tissues was higher after 7 days of exposure than after 3 days of exposure. Belpaeme and others (1998) also reported an increasing response with increasing exposure for brown trout (Salmo trutta fario) for up to 14 days after static renewal to EMS in water. These studies show that the Comet assay provides a relatively rapid indicator of exposure. Although there are no known long-term studies of the persistence of DNA damage in fish erythrocytes, these results and the fact that the lifespan of erythrocytes is probably only about 100 days (based on erythrocyte kinetics in other fish species) suggest that there is ongoing exposure of the brown bullhead in Ashumet Pond to genotoxic substances.

Although causation was not investigated during this study, some discussion is warranted, particularly because causation remains elusive without further research. External tumors are known to have a viral etiology in several species of fish, including white sucker (Catostomus Commersonii) (Baumann and Okihiro, 2000), but experimentation to date has not demonstrated a viral etiology in brown bullhead. Painting of brown bullhead with sediment extract containing PAHs from the Buffalo River, N.Y., produced skin tumors at a 38-percent prevalence after 2 years (Black and others, 1985). Similarly, epizootics of neoplasia in wild fish have been associated with contaminants (primarily PAHs) in freshwater, marine, and estuarine habitats in more than 20 locations in North America alone (Baumann, 1998). Even tumors having a partial viral etiology, such as papillomas on white suckers, have been more prevalent in populations from contaminated areas (Smith and others, 1989; Premdas and others, 1995). This observation indicates that tumor viruses may be activated at times of immune system dysfunction or inhibition caused by carcinogenic or immune-system suppressing compounds (Anders and Yoshimizu, 1994). Etiologies of such tumors would therefore be multifactoral (Premdas and Metcalfe, 1996). Similarly, parasite infections could cause tissue damage and thereby stimulate cell replication and increase the chances of tumor progression.

For Ashumet Pond, both the known PAH concentrations in sediment and PCE and TCE levels in water are far below concentrations known to induce tumors or tumor epizootics. It must be noted, however, that few studies using PCE and TCE have been conducted on fish. One study, involving ground water contaminated primarily with TCE (Gardner and others,
1998), found the ground water to be a tumor promoter but not a tumor initiator, although reagent-grade TCE did not have any tumor promoter effects. Gardner and others (1998) concluded that, although chemical analysis of the ground water found TCE to be the only reportable contaminant, other compounds below reportable limits may have had a synergistic effect on tumor promotion. Different mixes of chemical compounds can cause different suites of pathology (Yang and others, 2002).

The population pathology profiles differed for brown bullhead from Ashumet and Santuit Ponds. Large oral and medium body-surface lesions were more than twice as common, and large raised lesions on the body were more than four times as common, in Ashumet Pond fish than in Santuit Pond fish. These differences could be caused by the apparent younger age distribution of the Santuit Pond fish, or they also could be caused by differences in exposure to contaminant mixtures. The HSI for Ashumet Pond fish was greater than that for Santuit Pond fish. Similarly, dark skin patches were observed on almost two-thirds of the fish from Ashumet Pond, while none were seen on fish from Santuit Pond. Such melanistic patches have been associated with fish exposed to PAHs (Black, 1983; Black and others, 1985; Maccubbin and Ersing, 1991).

The high prevalence of melanistic lesions on Ashumet Pond brown bullhead, combined with the tumor pathology and genetic damage, implicates chemical carcinogens as one of the causal factors in that lake. Because many of the brown bullhead were very large and ages may have been underestimated, chemical exposure contributing to the pathology may have occurred as long ago as the early 1990s. Although there is no direct evidence of a link to contaminants from the MMR, remedial actions begun in the early 1990s have reduced and will continue to reduce the discharge of contaminants from the drainage system and ground-water plumes to Ashumet and Johns Ponds. The current (2008) brown bullhead population probably consists mostly of new individuals born since the 2002 sampling and the beginning of remediation efforts.

For these reasons, future studies could repeat the prevalence work at Ashumet and Santuit Ponds and at least one other reference lake to determine whether the pathology patterns have changed. The work could include, for at least 50 fish per lake, (1) measurement of length and weight, (2) recording of external lesions and preservation of samples (including all skin, oral, and barbel abnormalities) for histopathology, (3) determination of sex, (4) determination of age from analysis of otoliths and scales, and (5) preservation of liver samples for histopathology. In addition, for at least 20 fish per lake, the analysis could include (1) collection of bile for determination of PAH metabolites, (2) collection of samples from the kidneys and spleen for determination of macrophage aggregates, (3) preservation of liver samples for DNA adduct analysis, and (4) collection of blood samples from a subset of younger (1-2 years) and older (greater than 3 years) fish for Comet assays.

Additional studies could be conducted on the factors that may influence the elevated prevalence of neoplasms in brown 
bullhead from Ashumet and Santuit Ponds on the basis of the assumption that the causal factors may differ between the two lakes. These studies could include (1) environmental sampling of contaminants of concern in the lake water and sediments,

(2) cage studies in Ashumet Pond to test the pathological response of brown bullhead collected from a reference lake to exposure for 6-8 weeks to Ashumet Pond water and sediment, and (3) laboratory studies to examine possible synergistic effects of the combined exposure of brown bullhead to PAHs and volatile organic compounds.

\section{Summary}

Brown bullhead were sampled and examined for pathology from three lakes in southeastern Massachusetts-Ashumet, Santuit, and Great Herring Ponds. Fish from Great Herring Pond had low levels of raised lesions and low levels of genetic damage to red blood cell nuclei. Brown bullhead from Ashumet Pond, which has been subjected to contamination from the Massachusetts Military Reservation, had a high prevalence of raised lesions, which included histopathologically verified papillomas and squamous cell carcinoma, an elevated incidence of liver neoplasms, and an elevated level of genetic damage to red blood cell nuclei. Because red blood cells in fish have a lifespan of about 100 days, these results indicate an ongoing exposure to genotoxins in Ashumet Pond. Brown bullhead from Santuit Pond also had elevated prevalences of raised lesions and liver neoplasms, although the prevalences of large and multiple lesions were significantly lower than that in Ashumet Pond fish. These differences, along with additional differences in internal pathology, may point to differing causes of the raised lesions in the two lakes. The high prevalence of melanistic lesions on Ashumet Pond brown bullhead, combined with the tumor pathology and genetic damage, implicates chemical carcinogens as one of the causal factors in that lake. Because many of the brown bullhead were large and ages may have been underestimated, chemical exposure contributing to the pathology may have occurred as long ago as the early 1990s. An additional prevalence survey would help to clarify whether the causal factors are still active.

\section{Acknowledgments}

The authors would like to acknowledge the assistance of Daniel Peterson and Michael Rowan of Ohio State University; Andrew Massey, Joshua Koch, and Caroline Olson of the U.S. Geological Survey; and Ed Kraus, Jeff Breton, and Salvatore Paterno of the Massachusetts Division of Fisheries and Wildlife for their assistance in the field. We also thank the members of the Technical Review and Evaluation Team and Spence Smith of the Air Force Center for Engineering and the Environment for their advice and support during the design of the study, and Kathy Spring of the U.S. Geological Survey for preparation of the histopathology slides.

\section{References Cited}

\author{
U.S. Geological Survey reports can be obtained online at \\ http://infotrek.er.usgs.gov/pubs
}

Air Force Center for Engineering and the Environment (AFCEE), 2007, Groundwater plume maps \& information booklet: Massachusetts Military Reservation, Air Force Center for Engineering and the Environment, 36 p., accessed January 18, 2008, at http://www.mmr.org/2007 booklet.htm

Air Force Center for Engineering and the Environment (AFCEE), 2008a, Statement on fish health: Massachusetts Military Reservation, Installation Restoration Program, Administrative Record, document 18697, prepared for AFCEE by the Technical Review and Evaluation Team and dated April 28, 1998, accessed January 22, 2008, at http://cyberdocs.mmr.org/CyberDOCS/AdminRecord/ AFCEE/MMR_IRP/8/3/18697/q4v01_.PDF

Air Force Center for Engineering and the Environment (AFCEE), 2008b, Cape Cod fish papillomas - summary and recommendations from historical studies and site visits: Massachusetts Military Reservation, Installation Restoration Program, Administrative Record, document 18698, prepared for the Technical Review and Evaluation Team by P.C. Baumann and dated October 24, 2000, accessed January 22, 2008, at http://cyberdocs.mmr.org/CyberDOCS/ AdminRecord/AFCEE/MMR_IRP/8/3/18698/q5001_.PDF

Air Force Center for Engineering and the Environment (AFCEE), 2008c, Baumann report on fish papillomas: Massachusetts Military Reservation, Installation Restoration Program, Administrative Record, document 18699, prepared for AFCEE by the Technical Review and Evaluation Team and dated January 10, 2001, accessed January 22, 2008, at http://cyberdocs.mmr.org/CyberDOCS/AdminRecord/AFCEE/MMR_IRP/8/3/18699/q5101_.PDF

Air Force Center for Environmental Excellence (AFCEE), 1997, Fish health in the upper Cape Cod ponds near the Massachusetts Military Reservation, Plume Response Program, resource document: Otis Air National Guard Base, prepared for AFCEE by the Jacobs Engineering Group, Inc., AFC-J23-35K78412-M18-0001, July 1997, variously paged.

Air Force Center for Environmental Excellence (AFCEE), 1999, Final SD-5 South plume and adjacent TCE plume design data-gap technical memorandum: Massachusetts Military Reservation, Air Force Center for Environmental Excellence, Installation Restoration Program, AFC-J2335S18404-M17-0006, December 1999, variously paged. 
Air Force Center for Environmental Excellence (AFCEE), 2000, Final Chemical Spill 10 (CS-10) remedial investigation work plan: Massachusetts Military Reservation, Air Force Center for Environmental Excellence, Installation Restoration Program, AFC-J23-35U40202-M27-0004, June 2000, variously paged.

Air Force Center for Environmental Excellence (AFCEE), 2003, Ashumet Valley axial 2002 annual system performance and ecological monitoring report: Massachusetts Military Reservation, Air Force Center for Environmental Excellence, Installation Restoration Program, AFCEE ENRAC F41624-01-D-8545, December 2003, variously paged.

Air Force Center for Environmental Excellence (AFCEE), 2005, Ashumet Pond update, May 2005: Massachusetts Military Reservation, Air Force Center for Environmental Excellence, accessed January 19, 2008, at http://mmr.org/ cleanup/ponds/refdocs/APpost2005full.pdf

Anders, K., and Yoshimizu, M., 1994, Role of viruses in the induction of skin tumours and tumour-like proliferations of fish: Diseases of Aquatic Organisms, v. 19, p. 215-232.

Baumann, P.C., 1992, The use of tumors in wild populations of fish to assess ecosystem health: Journal of Aquatic Ecosystem Health, v. 1, p. 21-31.

Baumann, P.C., 1998, Epizootics of cancer in fish associated with genotoxins in sediment and water: Reviews in Mutation Research, v. 411, p. 227-233.

Baumann, P.C., Harshbarger, J.C., and Hartman, K.J., 1990, Relations of liver tumors to age structure of brown bullhead populations from two Lake Erie tributaries: Science of the Total Environment, v. 94, p. 71-88.

Baumann, P.C., Mac, M.J., Smith, S.B., and Harshbarger, J.C., 1991, Tumor frequencies in walleye (Stizostedion vitreum) and brown bullhead (Ictalurus nebulosus) and sediment contaminants in tributaries of the Laurentian Great Lakes: Canadian Journal of Fisheries and Aquatic Sciences, v. 48, p. 1804-1810.

Baumann, P.C., and Okihiro, M.S., 2000, Fish as a cancer model, in Ostrander, G.K., ed., The laboratory fish: London, Academic Press, p. 591-616.

Baumann, P.C., Smith, I.R., and Metcalfe, C.D., 1996, Linkages between chemical contaminants and tumors in benthic Great Lakes fishes: Journal of Great Lakes Research, v. 22, no. 2. p. 131-152.

Belpaeme, K., Cooreman, K., and Kirsch-Volders, M., 1998, Development and validation of the in vivo alkaline comet assay for detecting genomic damage in marine flatfish: Mutation Research, v. 415, p. 167-184.
Black, J.J., 1983, Epidermal hyperplasia and neoplasia in brown bullheads (Ictalurus nebulosus) in response to repeated applications of a PAH containing extract of polluted river sediment, in Cooke, M.W., and Dennis, A.J., eds., Polynuclear aromatic hydrocarbons - formation, metabolism, and measurement: Columbus, Ohio, Battelle Press, p. 99-111.

Black, J.J., Fox, H., Black, P., and Bock, F., 1985, Carcinogenic effects of river sediment extracts in fish and mice, in Jolley, R.L., Bull, R.J., Davis, W.P., Katz, S., Roberts, M.H., Jr., and Jacobs, V.A., eds., Water chlorination chemistry-environmental impact and health effects: Chelsea, Mich., Lewis Publishers, p. 415-427.

Blazer, V.S., Fournie, J.W., Wolf, J.C., and Wolfe, M.J., 2007, Manual for the microscopic diagnosis of proliferative liver and skin lesions in the brown bullhead (Ameiurus nebulosus): Erie, Penn., Pennsylvania Sea Grant, 34 p., accessed October 9, 2008, at http://seagrant.psu.edu/publications/ technicaldocs/HistoFieldManual.pdf

Chang, L.W., Toth, G.P., Gordon, D.A., Graham, D.W., Meier, J.R., Knapp, C.W., DeNoyelles, F.J., Jr., Campbell, S., and Lattier, D.L., 2005, Responses of molecular indicators of exposure in mesocosms - Common carp (Cyprinus carpio) exposed to the herbicides alachlor and atrazine: Environmental Toxicology and Chemistry, v. 24, p. 190-197.

Devaux, A., Flammarion, P., Bernardon, V., Garric, J., and Monod, G., 1998, Monitoring of the chemical pollution of the River Rhône through measurement of DNA damage and cytochrome P4501A induction in chub (Leuciscus cephalus): Marine Environmental Research, v. 46, p. 257-262.

Fabacher, D.L., and Baumann, P.C., 1985, Enlarged livers and hepatic microsomal mixed function oxidase components in tumor bearing brown bullheads from a chemically contaminated river: Environmental Toxicology and Chemistry, v. 4, p. 703-710.

Gardner, H.S., Brennan, L.M., Toussaint, M.W., Rosencrance, A.B., Boncavage-Hennessey, E.M., and Wolfe, M.J., 1998, Environmental complex mixture toxicity assessment: Environmental Health Perspectives, v. 106, no. 6, p. 1299-1305.

Hansen, B.P., and Lapham, W.W., 1990, Geohydrology and simulated ground-water flow, Plymouth-Carver Aquifer, southeastern Massachusetts: U.S. Geological Survey WaterResources Investigations Report 90-4204, 69 p., 1 app., 2 pls. 
Hazardous Waste Remedial Actions Program (HAZWRAP), 1986, Air National Guard, Camp Edwards (ARNG), U.S. Air Force, and Veteran's Administration facilities at Massachusetts Military Reservation, Massachusettsphase 1 records search: Hazardous Waste Remedial Actions Program, Oak Ridge National Laboratory, prepared for the Installation Restoration Program, U.S. Air Force, final report, task 6, December 11, 1986, variously paged.

Hazardous Waste Remedial Actions Program (HAZWRAP), 1995, Ashumet and Johns Ponds 1993 annual report: Hazardous Waste Remedial Actions Program, Oak Ridge National Laboratory, prepared for the Installation Restoration Program, Air National Guard, Massachusetts Military Reservation, June 1995, variously paged.

Hazardous Waste Remedial Actions Program (HAZWRAP), 1996, Ashumet and Johns Ponds 1994 annual report: Hazardous Waste Remedial Actions Program, Oak Ridge National Laboratory, prepared for the Installation Restoration Program, Air National Guard, Massachusetts Military Reservation, August 1996, variously paged.

International Agency for Research on Cancer (IARC), 1997, Dry cleaning, some chlorinated solvents and other industrial chemicals - summary of data reported and evaluations: World Health Organization, International Agency for Research on Cancer, IARC Monographs on the Evaluation of Carcinogenic Risks to Humans, v. 63, updated May 14, 1997, accessed January 18, 2007, at http://monographs.iarc. fr/ENG/Monographs/vol63/volume63.pdf

K-V Associates, Inc., and IEP, Inc., 1991, Ashumet Pond, a diagnostic/feasibility study: Falmouth, Mass., K-V Associates, Inc., and IEP, Inc., prepared for the towns of Falmouth and Mashpee, Mass., and the Clean Lakes Program, Massachusetts Department of Environmental Protection, v. 1, January 1991, 158 p.

LeBlanc, D.R., Guswa, J.H., Frimpter, M.H., and Londquist, C.J., 1986, Ground-water resources of Cape Cod, Massachusetts: U.S. Geological Survey Hydrologic-Investigations Atlas HA-692, 4 sheets, scale 1:48,000.

Luna, L.G., 1992, Histopathologic methods and color atlas of special stains and tissue artifacts: Gaithersburg, Md., American Histolabs, Inc., 767 p.

Maccubbin, A.E., and Ersing, N., 1991, Tumors in fish from the Detroit River: Hydrobiologia, v. 219, p. 301-306.

Maceina, M.J., and Sammons, S.M., 2006, An evaluation of different structures to age freshwater fish from a northeastern U.S. river: Fisheries Management and Ecology, v. 13, p. 237-242.
Massachusetts Division of Fisheries and Wildlife (MADFW), 2008, State pond maps: Westborough, Mass., Massachusetts Department of Fisheries and Wildlife, accessed January 18, 2008, at http://www.mass.gov/dfwele/dfw/habitat/ maps/ponds/pond_maps.htm

Massachusetts National Guard (MANG), 2008, MMR history: Massachusetts Military Reservation, Camp Edwards, Massachusetts National Guard Environmental \& Readiness Center, accessed January 18, 2008, at http://www.mass.gov/ guard/E\&RC/mmrhistory1.htm

Masterson, J.P., Stone, B.D., Walter, D.A., and Savoie, Jennifer, 1997, Hydrogeologic framework of western Cape Cod, Massachusetts: U.S. Geological Survey HydrologicInvestigations Atlas HA-741, 1 pl.

Masterson, J.P., and Walter, D.A., 2000, Delineation of ground-water recharge areas, western Cape Cod, Massachusetts: U.S. Geological Survey Water-Resources Investigations Report 00-4000, 1 pl.

Masterson, J.P., Walter, D.A., and LeBlanc, D.R., 1998, Delineation of contributing areas to selected public-supply wells, western Cape Cod, Massachusetts: U.S. Geological Survey Water-Resources Investigations Report 98-4237, 45 p.

McCobb, T.D., LeBlanc, D.R., Walter, D.A., Hess, K.M., Kent, D.B., and Smith, R.L., 2003, Phosphorus in a groundwater contaminant plume discharging to Ashumet Pond, Cape Cod, Massachusetts, 1999: U.S. Geological Survey Water-Resources Investigations Report 02-4306, 69 p.

Mueller, M.E., and Mac, M.J., 1994, Fish tumors and abnormalities: U.S. Environmental Protection Agency, Assessment and Remediation of Contaminated Sediments (ARCS) Program, assessment guidance document EPA 905-B94002 .

Obert, E.C., 1994, Presque Isle Bay brown bullhead tumor study conducted from March 29, 1992, to October 7, 1993: Pennsylvania Department of Environmental Resources, Bureau of Water Management, Northwest Region.

Oldale, R.N., and Barlow, R.A., 1986, Geologic map of Cape Cod and the Islands, Massachusetts: U.S. Geological Survey Miscellaneous Investigations Series Map I-1763, scale 1:100,000.

Pandrangi, R., Petras, M., Ralph, S., and Vrzoc, M., 1995, Alkaline single cell gel (comet) assay and genotoxicity monitoring using bullheads and carp: Environmental and Molecular Mutagenesis, v. 26, p. 345-356.

Pinkney, A.E., Harshbarger, J.C., May, E.B., and Melancon, M.J., 2001, Tumor prevalence and biomarkers of exposure in brown bullheads (Ameiurus nebulosus) from the tidal Potomac River, U.S.A., watershed: Environmental Toxicology and Chemistry, v. 20, p. 1196-1205. 
Pinkney, A.E., Harshbarger, J.C., May, E.B., and Reichert, W.L., 2004, Tumor prevalence and biomarkers of exposure and response in brown bullhead (Ameiurus nebulosus) from the Anacostia River, Washington, D.C., and Tuckahoe River, Maryland, U.S.A.: Environmental Toxicology and Chemistry, v. 23, p. 638-647.

Premdas, P.D., and Metcalfe, C.D., 1996, Experimental transmission of epidermal lip papilloma in white suckers, Catostomus commersoni: Canadian Journal of Fisheries and Aquatic Science, v. 53, p. 1018-1029.

Premdas, P.D., Metcalfe, T.L., Bailey, M.E., and Metcalfe, C.D., 1995, The prevalence and histological appearance of lip papilloma in white suckers (Catostomus commersoni) from two sites in central Ontario, Canada: Journal of Great Lakes Research, v. 21, p. 207-218.

Rafferty, Sean, and Grazio, Jim, 2006, Field manual for assessing internal and external anomalies in brown bullhead: Erie, Penn., Pennsylvania Sea Grant, 34 p., accessed October 9, 2008, at http://seagrant.psu.edu/publications/ technicaldocs/BullheadFieldManual.pdf

Rolbein, Seth, 1995, The enemy within - the struggle to clean up Cape Cod's military Superfund site: Orleans, Mass., Association for the Preservation of Cape Cod, $175 \mathrm{p}$.

Savoie, J.G., LeBlanc, D.R., Blackwood, D.S., McCobb, T.D., Rendigs, R.R., and Clifford, Scott, 2000, Delineation of discharge areas of two contaminant plumes by use of diffusion samplers, Johns Pond, Cape Cod, Massachusetts, 1998: U.S. Geological Survey Water-Resources Investigations Report 00-4017, 30 p.

Schmitt, C.J., Blazer, V.S., Dethloff, G.M., Tillitt, D.E., Gross, T.S., Bryant, W.L., DeWeese, L.R., Smith, S.B., Goede, R.W., Bartish, T.M., and Kubiak, T.J., 1999, Biomonitoring of environmental status and trends (BEST) program-field procedures for assessing the exposure of fish to environmental contaminants: U.S. Geological Survey Information and Technology Report USGS/BRD-1999-0007, 68 p.

Scott, W.B., and Crossman, E.J., 1973, Freshwater fishes of Canada: Ottawa, Fisheries Research Board of Canada, Canada Bulletin 184, 966 p.

Singh, N.P., McCoy, M.T., Tice, R.R., and Schneider, E.L., 1988, A simple technique for quantitation of low levels of DNA damage in individual cells: Experimental Cell Research, v. 175, p. 184-191.

Smith, I.R., Ferguson, H.W., and Hayes, M.A., 1989, Histopathology and prevalence of epidermal papilloma epidemic in brown bullhead, Ictalurus nebulosus (Lesueur), and white sucker, Catostomus sommersoni (Lacepede) populations from Ontario, Canada: Journal of Fish Diseases, v. 12, p. 373-388.
Stegeman, J.J., 1997, Biomarkers in fish from Cape Ponds, in Air Force Center for Environmental Excellence (AFCEE), Fish health in the upper Cape Cod ponds near the Massachusetts Military Reservation, Plume Response Program, resource document: Otis Air National Guard Base, prepared for AFCEE by the Jacobs Engineering Group, Inc., AFC-J23-35K78412-M18-0001, July 1997, variously paged.

Tice, R.R., 1995, The single cell gel/Comet assay - a microgel electrophoretic technique for the detection of DNA damage and repair in individual cells, in Phillips, D.H., and Venitt, S., eds., Environmental mutagenesis: Oxford, United Kingdom, Bios Scientific Publishers, Ltd., p. 315-339.

U.S. Army Environmental Command (USAEC), 2007a, Impact Area Groundwater Study Program, overview and update - transitioning to cleanup: Camp Edwards, Massachusetts Military Reservation, U.S. Army Environmental Command, Fact Sheet 2007-05, spring 2007, 8 p., accessed January 18, 2008, at http://groundwaterprogram.army.mil/ community/facts/overview-2007.pdf

U.S. Army Environmental Command (USAEC), 2007b, Impact Area Groundwater Study Program, investigation and cleanup update: Camp Edwards, Massachusetts Military Reservation, U.S. Army Environmental Command, fact sheet, summer 2007, 32 p., accessed January 18, 2008, at http:/groundwaterprogram.army.mil/community/facts/ MMR_Plume_Book_2007_vFINAL_HiRes.pdf

Walter, D.A., Masterson, J.P., and LeBlanc, D.R., 2002, Simulated pond-aquifer interactions under natural and stressed conditions near Snake Pond, Cape Cod, Massachusetts: U.S. Geological Survey Water-Resources Investigations Report 99-4174, 35 p.

Walter, D.A., Rea, B.A., Stollenwerk, K.G., and Savoie, Jennifer, 1996, Geochemical and hydrologic controls on phosphorus transport in a sewage-contaminated sand and gravel aquifer near Ashumet Pond, Cape Cod, Massachusetts: U.S. Geological Survey Water-Supply Paper 2463, $89 \mathrm{p}$.

Walter, D.A., and Whealan, A.T., 2005, Simulated water sources and effects of pumping on surface and ground water, Sagamore and Monomoy flow lenses, Cape Cod, Massachusetts: U.S. Geological Survey Scientific Investigations Report 2004-5181, 85 p.

Winter, M.J., Day, N., Hayes, R.A., Taylor, E.W., Butler, P.J., and Chipman, J.K., 2004, DNA strand breaks and adducts determined in feral and caged chub (Leuciscus cephalus) exposed to rivers exhibiting variable water quality around Birmingham, United Kingdom: Mutation Research, v. 552, p. $163-175$. 
Yang, X., and Baumann, P.C., 2006, Biliary PAH metabolites and the hepatosomatic index of brown bullheads from Lake Erie tributaries: Ecological Indicators, v. 6, no. 3, p. $567-574$.

Yang, X., Meier, J.R., Chang, L., Rowan, M., and Baumann, P.C., 2006, DNA damage and external lesions in brown bullheads (Ameiurus nebulosus) from contaminated habitats: Environmental Toxicology and Chemistry, v. 25, p. $3035-3038$.

Yang, X., Peterson, D.S., Baumann, P.C., and Lin, E.L.C., 2002, Fish biliary PAH metabolites estimated by fixedwavelength fluorescence as an indicator of environmental exposure and effects: Journal of Great Lakes Research, v. 29 , no. 1 , p. 116-123. 


\section{Glossary}

C

carcinoma Malignant neoplastic lesions with invasion into the surrounding tissue.

E

epizootic A disease that is prevalent among a group of animals.

etiology The cause of a disease or disorder.

H

histopathology Microscopic examination of tissue pathology.

L

Iesion Any grossly visible or microscopic abnormality, including parasites, inflammation, reddened areas, eroded areas, and raised growths.

M

melanistic Abnormally darkened areas of skin.

N

neoplasm New, abnormal, unregulated, or uncoordinated growth of specific cell types.

0

otolith Bone that is part of the ear of the fish.

P

papilloma Benign neoplastic lesions composed of proliferating, but not invasive, epidermal cells.

pathology The study and diagnosis of disease through the examination of organs, tissues, bodily fluids, and whole bodies.

R

reference lake A lake believed to be "unpolluted" by the contaminants of concern that serves as an "uncontaminated" background site for comparison to the lake of interest.

T

tumor By strict definition, a raised growth, but often used interchangeably with cancer or neoplasm. 
THIS PAGE INTENTIONALLY LEFT BLANK 
Appendixes 1 and 2 


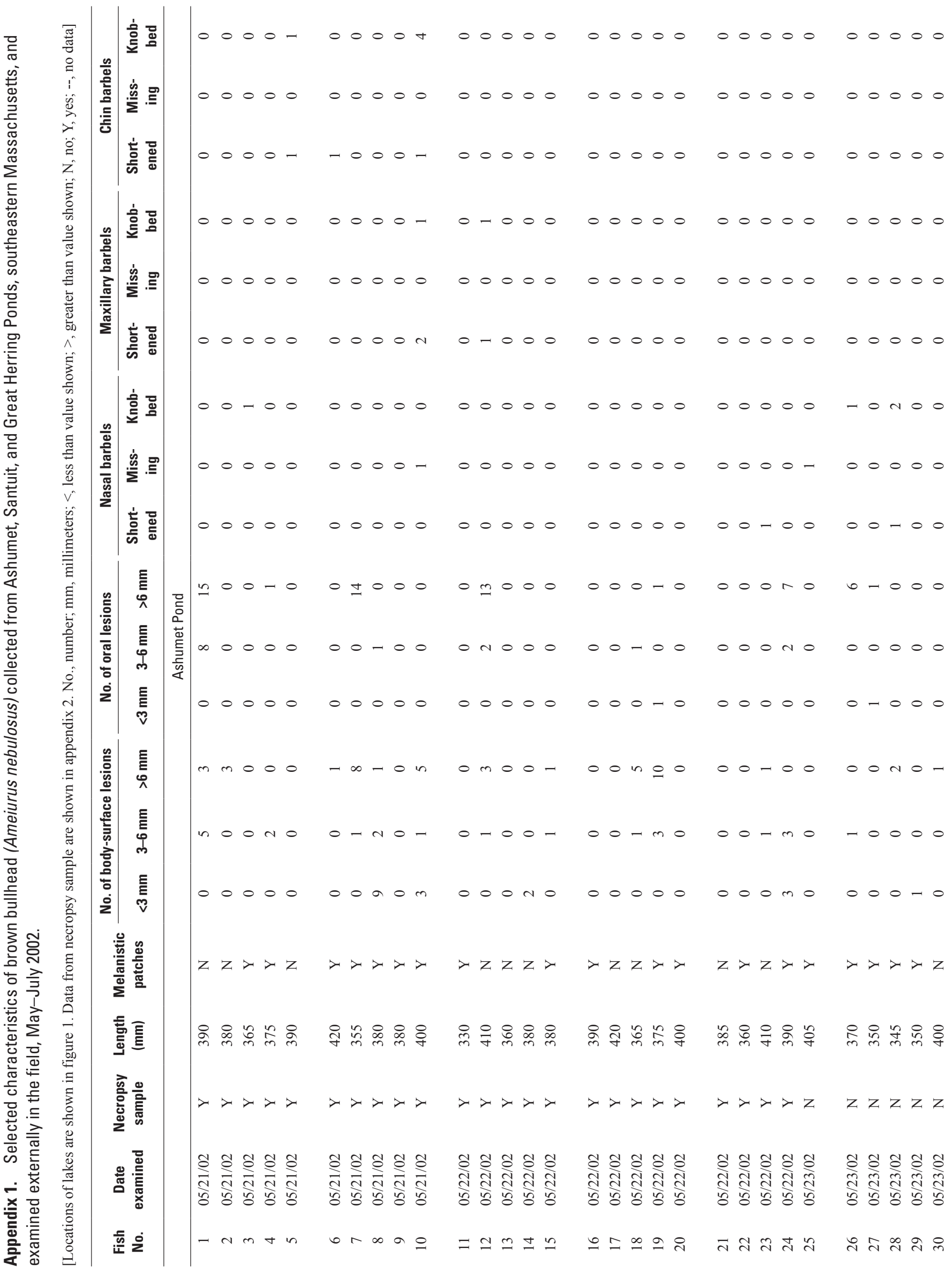




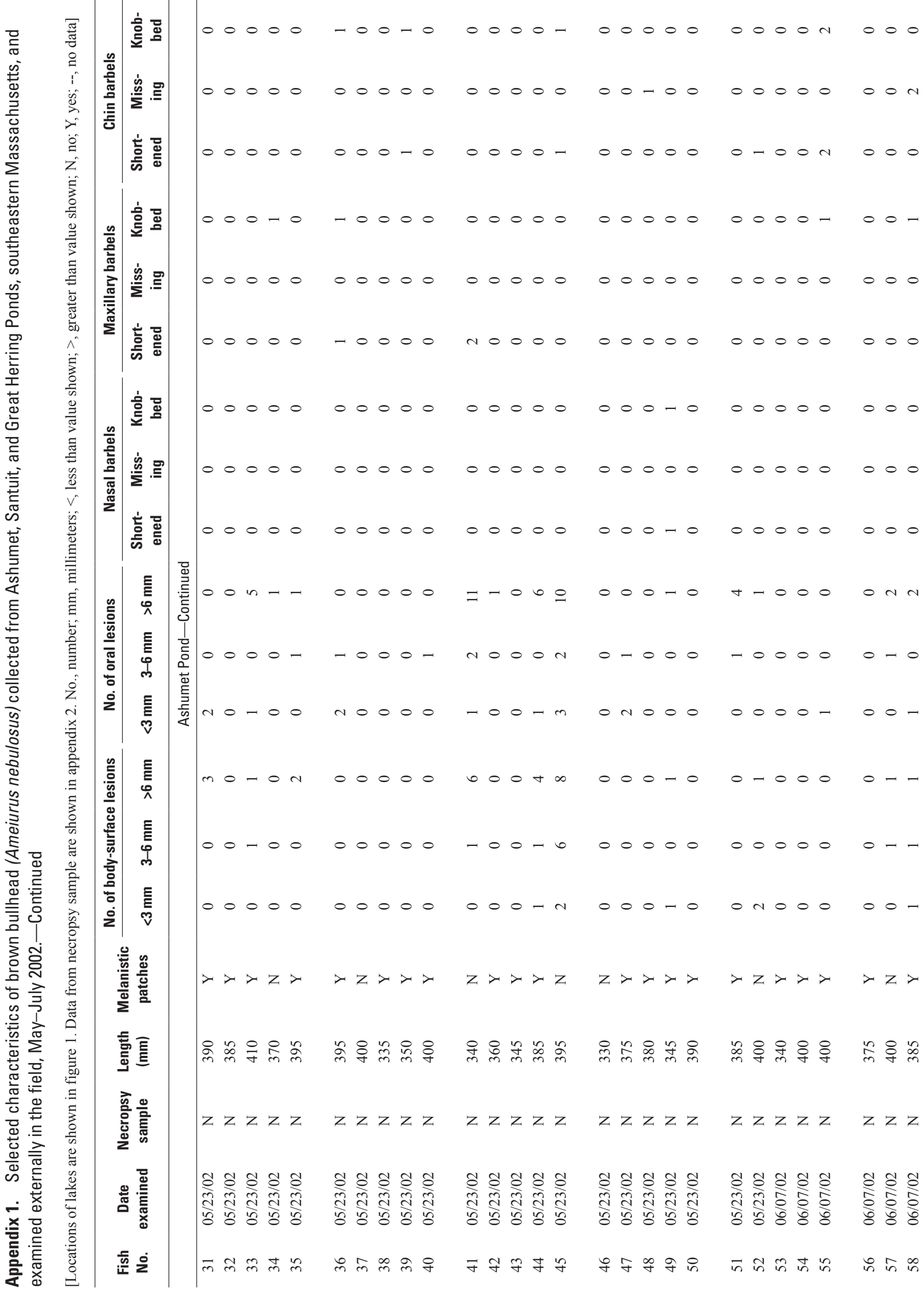




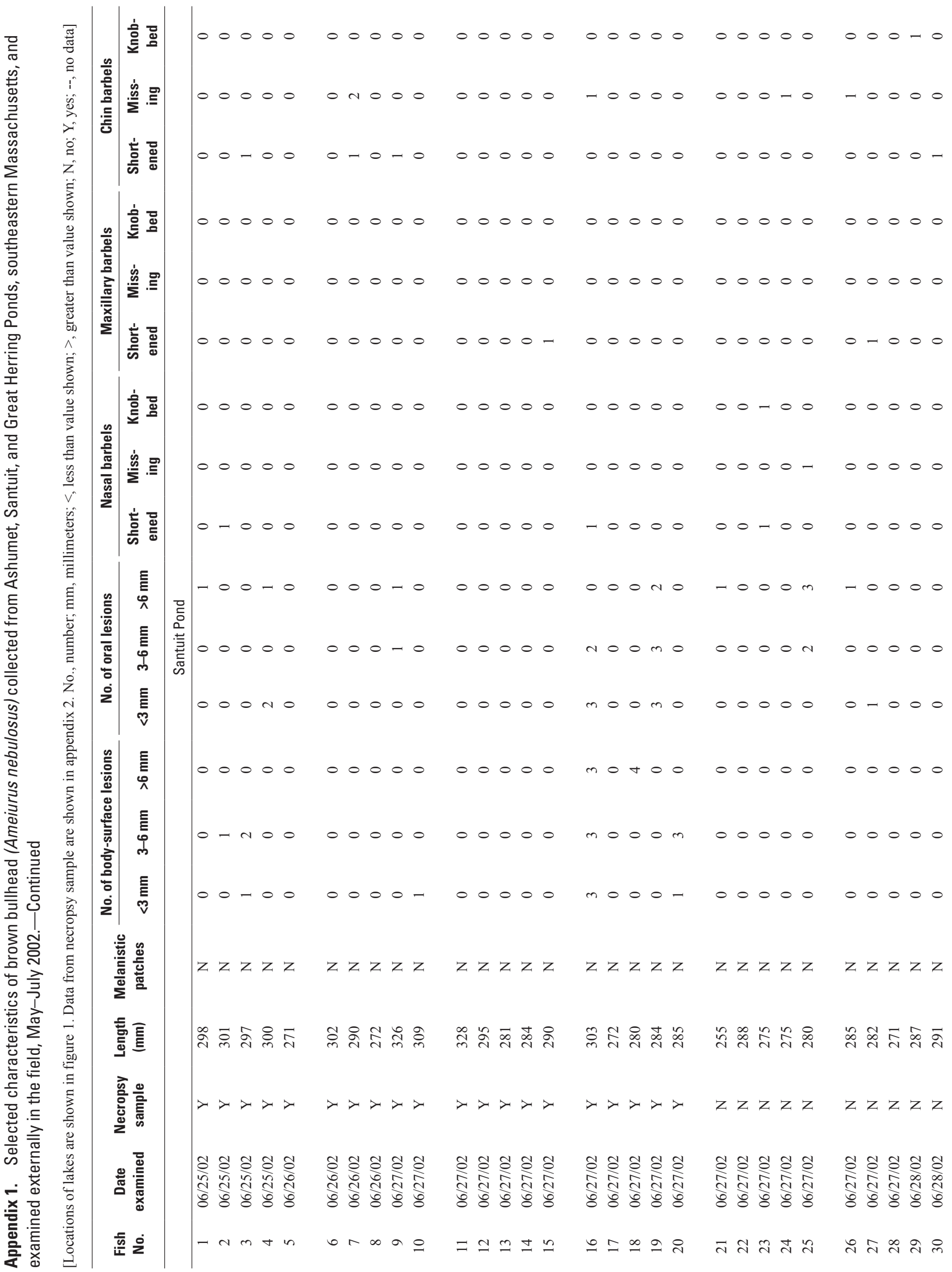




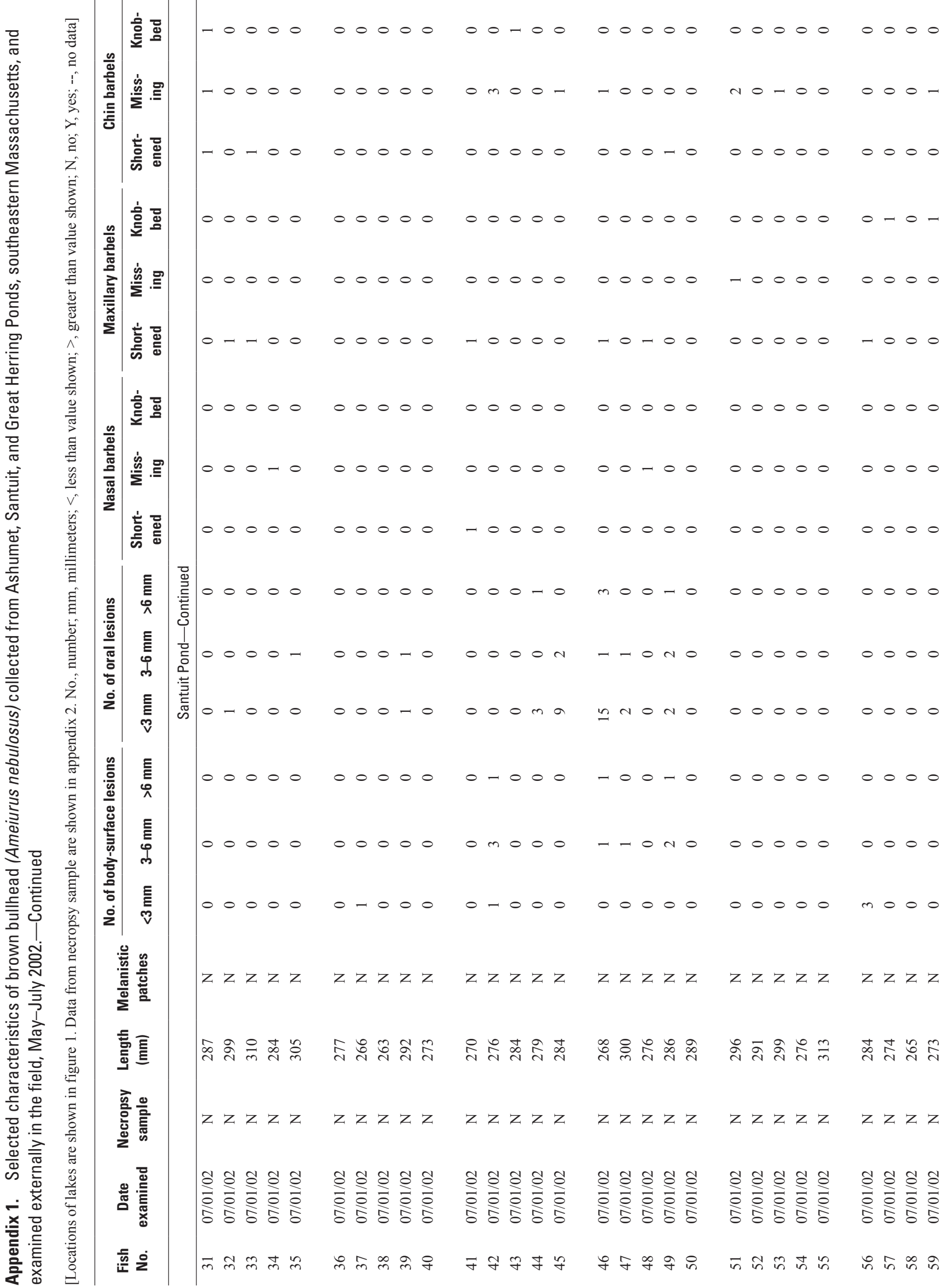




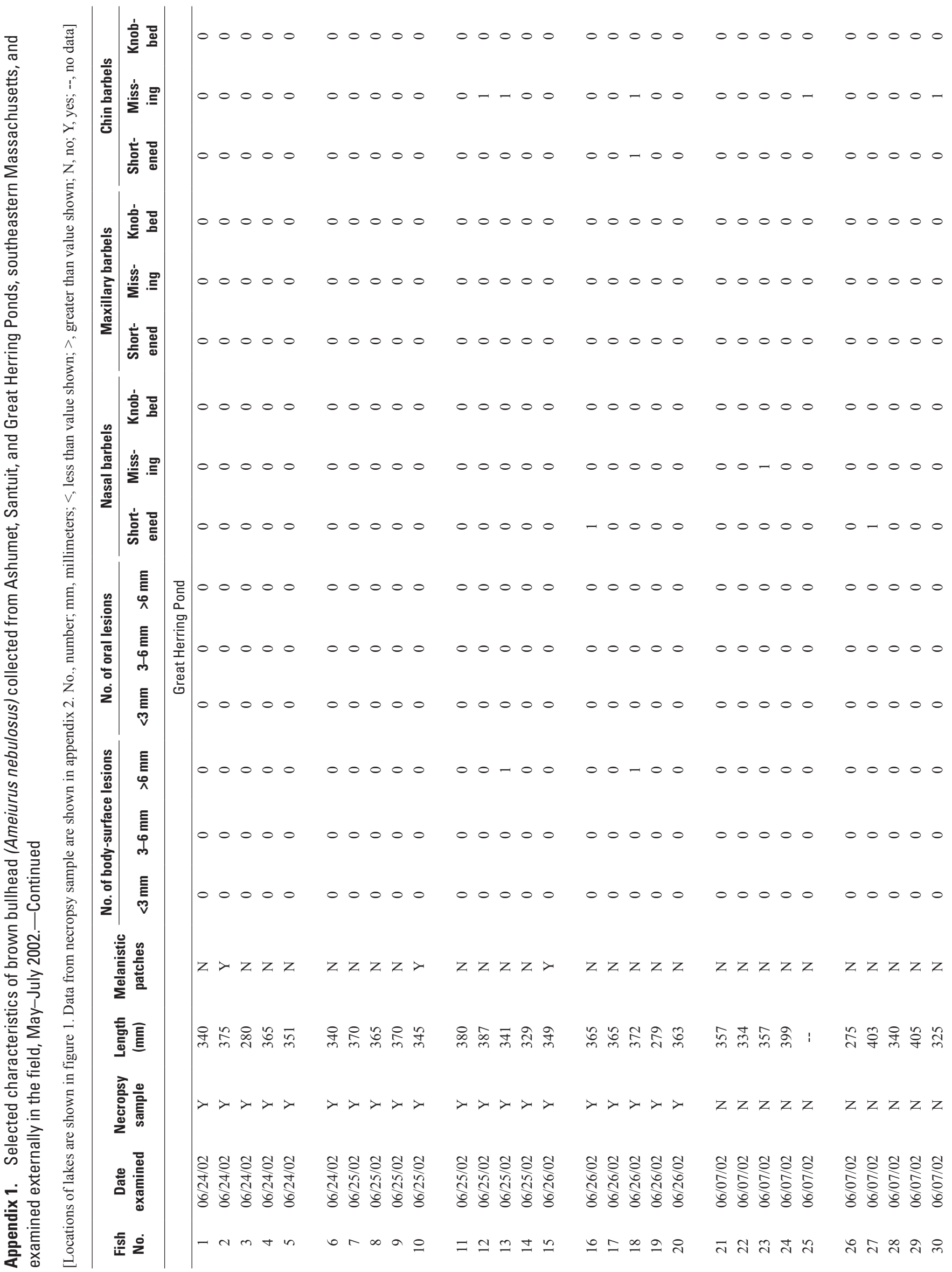




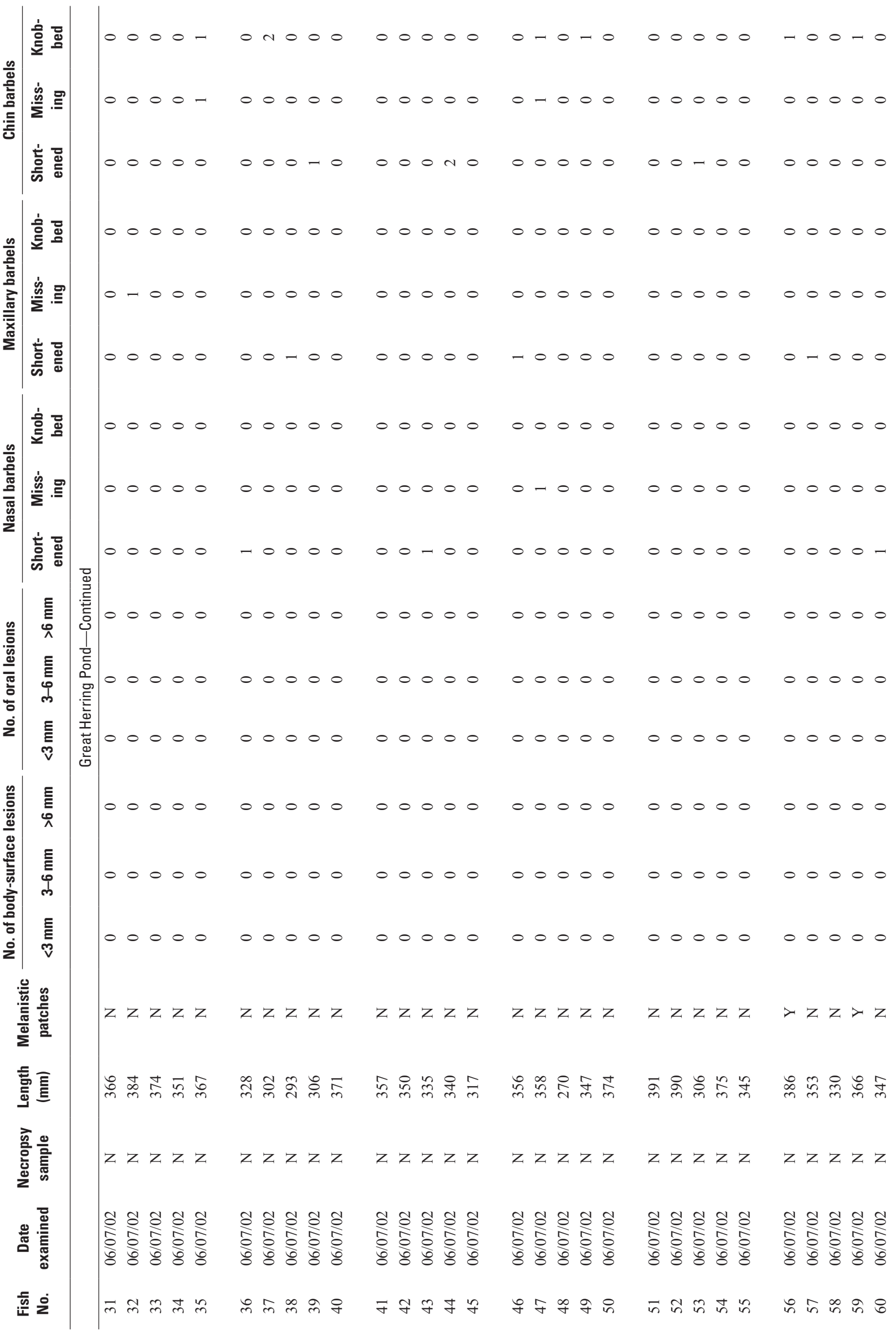




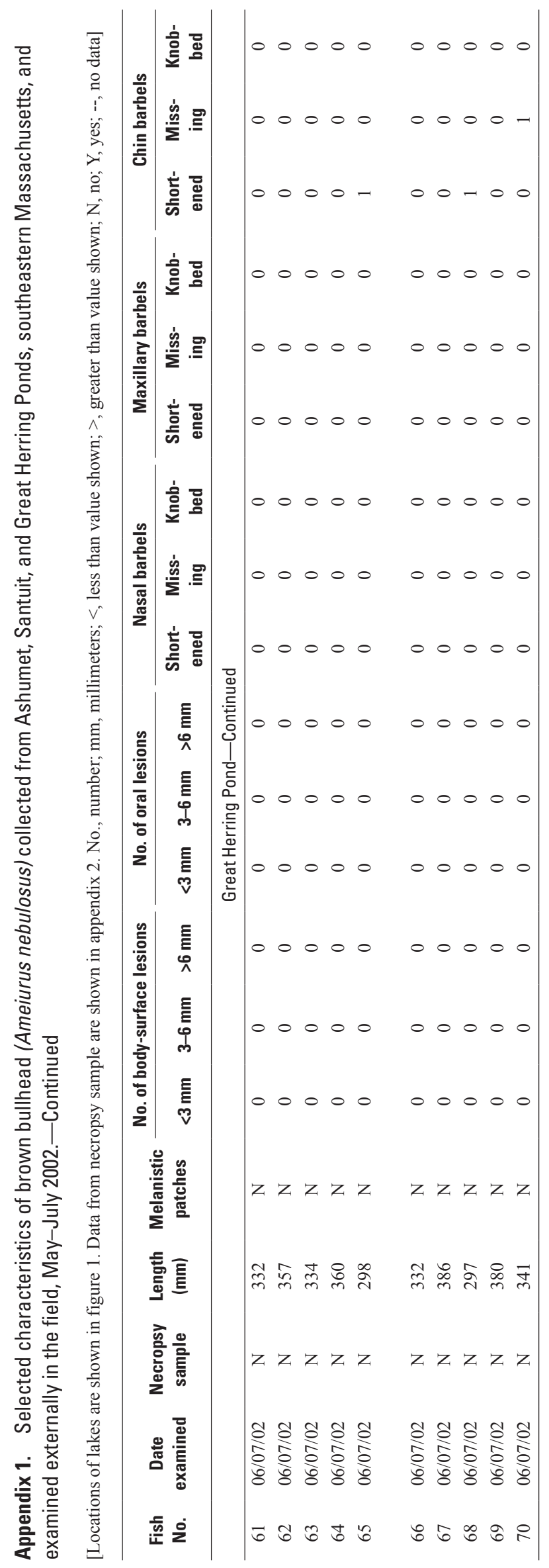


Appendix 2. Selected characteristics of brown bullhead (Ameiurus nebulosus) collected from Ashumet, Santuit, and Great Herring Ponds, southeastern Massachusetts, and necropsied for internal examination and tissue sampling, May-June 2002.

[Locations of lakes are shown in figure 1. Data from external examination are shown in appendix 1. No., number; mm, millimeters; g, grams; yr, year; HSI, hepatosomatic index; M, male; F, female; --, no data]

\begin{tabular}{|c|c|c|c|c|c|c|c|c|c|}
\hline Fish No. & $\begin{array}{c}\text { Date } \\
\text { necropsied }\end{array}$ & $\begin{array}{c}\text { Length } \\
(\mathrm{mm})\end{array}$ & $\begin{array}{c}\text { Weight } \\
\text { (g) }\end{array}$ & Sex & $\begin{array}{c}\text { Estimated age } \\
(y r)\end{array}$ & $\begin{array}{l}\text { Liver weight } \\
\text { (g) }\end{array}$ & HSI & $\begin{array}{c}\text { Gonads weight } \\
\text { (g) }\end{array}$ & $\begin{array}{c}\text { Spleen weight } \\
\text { (g) }\end{array}$ \\
\hline \multicolumn{10}{|c|}{ Ashumet Pond } \\
\hline 2 & $05 / 21 / 02$ & 380 & 905 & $\mathrm{M}$ & 4 & 23.38 & .026 & 2.37 & 1.48 \\
\hline 3 & $05 / 21 / 02$ & 365 & 820 & $\mathrm{~F}$ & 3 & 22.75 & .028 & 72.30 & 1.06 \\
\hline 6 & $05 / 21 / 02$ & 420 & 1,095 & $\mathrm{M}$ & 7 & 23.43 & .021 & 2.99 & 1.57 \\
\hline 7 & $05 / 21 / 02$ & 355 & 694 & $\mathrm{~F}$ & 5 & 28.90 & .042 & 14.93 & 1.49 \\
\hline 8 & $05 / 21 / 02$ & 380 & 917 & $\mathrm{~F}$ & 5 & 24.56 & .027 & 76.33 & 1.67 \\
\hline 11 & $05 / 22 / 02$ & 330 & 668 & $\mathrm{~F}$ & 7 & 13.53 & .020 & 68.59 & 0.67 \\
\hline 12 & $05 / 22 / 02$ & 410 & 1,045 & M & 7 & 18.60 & .018 & 4.27 & 1.19 \\
\hline 13 & $05 / 22 / 02$ & 360 & 780 & M & 5 & 17.10 & .022 & 2.34 & 1.47 \\
\hline 14 & $05 / 22 / 02$ & 380 & 1,000 & $\mathrm{~F}$ & 4 & 32.79 & .033 & 79.32 & 1.24 \\
\hline 15 & $05 / 22 / 02$ & 380 & 975 & M & 4 & 23.40 & .024 & 2.75 & 1.12 \\
\hline 16 & $05 / 22 / 02$ & 390 & 1,023 & M & 7 & 22.84 & .022 & 3.43 & 2.13 \\
\hline 17 & $05 / 22 / 02$ & 420 & 1,120 & M & 8 & 24.29 & .022 & 3.58 & 1.75 \\
\hline 18 & $05 / 22 / 02$ & 365 & 851 & $\mathrm{~F}$ & 6 & 26.50 & .031 & 69.92 & 2.87 \\
\hline 24 & $05 / 22 / 02$ & 390 & 871 & $\mathrm{M}$ & 9 & 17.71 & .020 & 1.87 & 2.36 \\
\hline \multicolumn{10}{|c|}{ Santuit Pond } \\
\hline 1 & $06 / 25 / 02$ & 298 & 376 & $\mathrm{M}$ & 4 & 4.97 & .016 & 1.38 & .63 \\
\hline 2 & $06 / 25 / 02$ & 301 & 380 & M & 6 & 7.50 & .020 & 0.86 & .54 \\
\hline 3 & $06 / 25 / 02$ & 297 & 351 & $\mathrm{M}$ & 4 & 4.17 & .012 & 1.13 & .33 \\
\hline 4 & $06 / 25 / 02$ & 300 & 342 & $\mathrm{M}$ & 3 & 4.61 & .013 & .42 & .40 \\
\hline 5 & $06 / 26 / 02$ & 271 & 306 & $\mathrm{~F}$ & 5 & 5.10 & .017 & 36.71 & .35 \\
\hline 6 & $06 / 26 / 02$ & 302 & 357 & M & 4 & 4.70 & .013 & 1.33 & .62 \\
\hline 7 & $06 / 26 / 02$ & 290 & 300 & $\mathrm{~F}$ & 3 & 4.46 & .015 & 32.13 & .31 \\
\hline 8 & $06 / 26 / 02$ & 272 & 262 & $\mathrm{~F}$ & 3 & 5.19 & .020 & -- & .33 \\
\hline 9 & $06 / 27 / 02$ & 326 & 481 & M & 7 & 9.08 & .019 & 1.16 & .73 \\
\hline 10 & $06 / 27 / 02$ & 309 & 409 & M & 3 & 6.22 & .015 & .89 & .68 \\
\hline
\end{tabular}


Appendix 2. Selected characteristics of brown bullhead (Ameiurus nebulosus) collected from Ashumet, Santuit, and Great Herring Ponds, southeastern Massachusetts, and necropsied for internal examination and tissue sampling, May-June 2002.—Continued

[Locations of lakes are shown in figure 1. Data from external examination are shown in appendix 1. No., number; mm, millimeters; g, grams; yr, year; HSI, hepatosomatic index; M, male; F, female; --, no data]

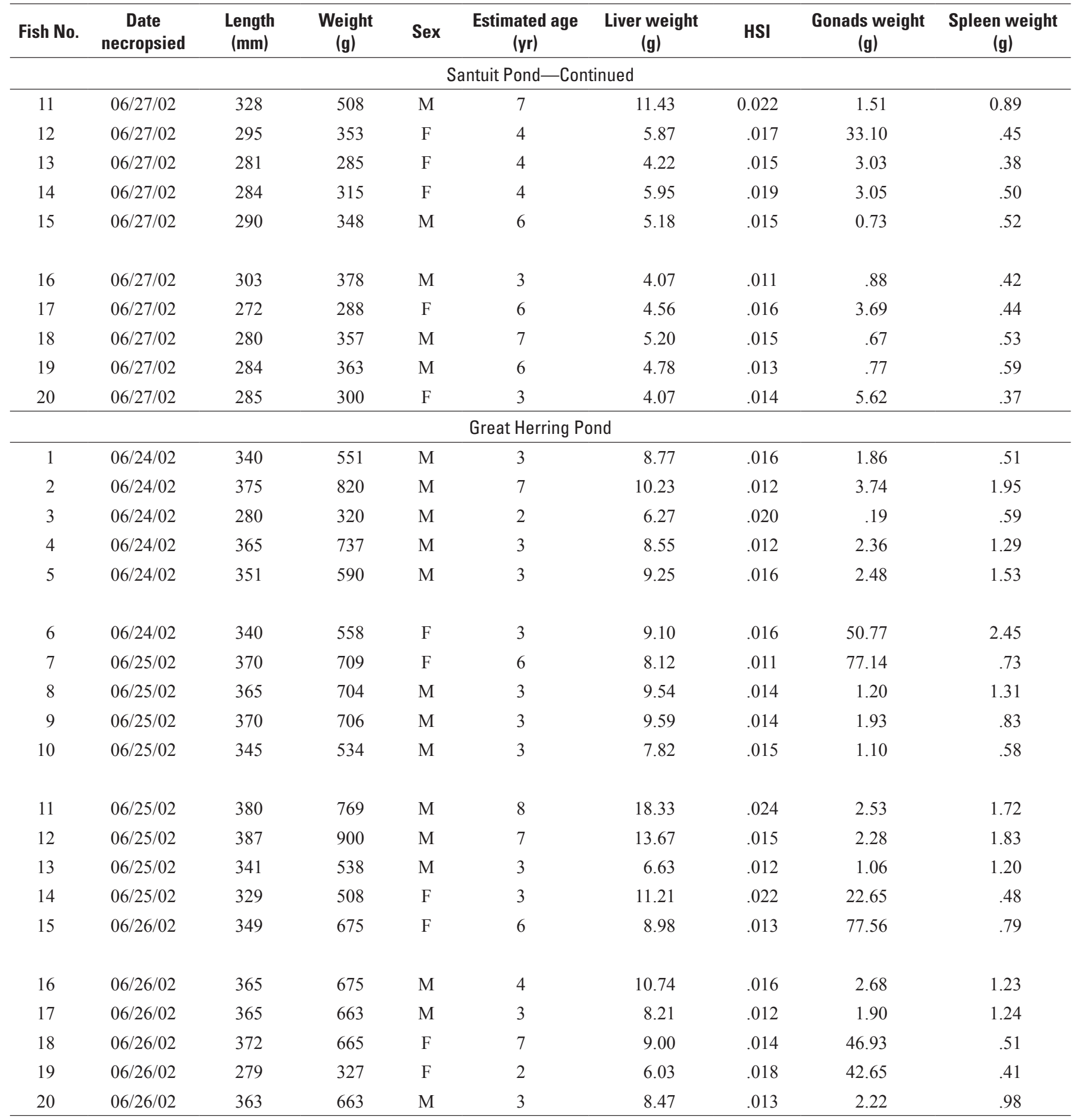


Prepared by the Pembroke Publishing Service Center.

For more information concerning this report, contact:

Director

U.S. Geological Survey

Massachusetts-Rhode Island Water Science Center

10 Bearfoot Road

Northborough, MA 01532

dc_ma@usgs.gov

or visit our Web site at:

http://ma.water.usgs.gov 
